\title{
Orexin-Corticotropin-Releasing Factor Receptor Heteromers in the Ventral Tegmental Area as Targets for Cocaine
}

\author{
Gemma Navarro, ${ }^{1 *}$ César Quiroz, ${ }^{2 *}$ ○David Moreno-Delgado, ${ }^{1 *}$ Adam Sierakowiak, ${ }^{2}$ Kimberly McDowell, ${ }^{2}$ \\ Estefanía Moreno, ${ }^{1}$ William Rea, ${ }^{2}$ Ning-Sheng Cai, ${ }^{2}$ David Aguinaga, ${ }^{1}$ Lesley A. Howell, ${ }^{3}$ Felix Hausch, ${ }^{4}$ Antonio Cortés, ${ }^{1}$ \\ - Josefa Mallol, ${ }^{1}$ Vicent Casadó, ${ }^{1}$ CCarme Lluís, ${ }^{1}$ Enric I. Canela, ${ }^{\dagger}{ }^{\dagger}$ Sergi Ferré, ${ }^{\dagger \dagger}$ and Peter J. McCormick ${ }^{1,3{ }^{\dagger}}$ \\ ${ }^{1}$ Department of Biochemistry and Molecular Biology, Faculty of Biology, University of Barcelona, Center for Biomedical Research in Neurodegenerative \\ Diseases Network and Institute of Biomedicine of the University of Barcelona, 08028 Barcelona, Spain, ${ }^{2}$ Integrative Neurobiology Section, National Institute \\ on Drug Abuse, Intramural Research Program, National Institutes of Health, Baltimore, Maryland 21224, ${ }^{3}$ School of Pharmacy, University of East Anglia, \\ Norwich, NR4 7TJ, United Kingdom, and ${ }^{4}$ Max Planck Institute of Psychiatry, 80804 Munich, Germany
}

Release of the neuropeptides corticotropin-releasing factor (CRF) and orexin-A in the ventral tegmental area (VTA) play an important role in stress-induced cocaine-seeking behavior. We provide evidence for pharmacologically significant interactions between CRF and orexin- $A$ that depend on oligomerization of $C R F_{1}$ receptor $\left(C R F_{1} R\right)$ and orexin $O X_{1}$ receptors $\left(O X_{1} R\right)$. $C R F_{1} R-O X_{1} R$ heteromers are the conduits of a negative crosstalk between orexin-A and CRF as demonstrated in transfected cells and rat VTA, in which they significantly modulate dendritic dopamine release. The cocaine target $\sigma_{1}$ receptor $\left(\sigma_{1} \mathrm{R}\right)$ also associates with the $\mathrm{CRF}_{1} \mathrm{R}-0 \mathrm{X}_{1} \mathrm{R}$ heteromer. Cocaine binding to the $\sigma_{1} \mathrm{R}-\mathrm{CRF}_{1} \mathrm{R}-\mathrm{OX}_{1} \mathrm{R}$ complex promotes a long-term disruption of the orexin-A-CRF negative crosstalk. Through this mechanism, cocaine sensitizes VTA cells to the excitatory effects of both CRF and orexin-A, thus providing a mechanism by which stress induces cocaine seeking.

Key words: cocaine; CRF receptor; GPCR heteromer; orexin receptor; sigma receptor

\section{Introduction}

The 41 aa neuropeptide corticotropin-releasing factor (CRF) plays an important role in stress-induced drug-seeking behavior (Sarnyai et al., 2001). This depends primarily on CRF release in the ventral tegmental area (VTA), which receives CRF inputs from the paraventricular nucleus and the limbic forebrain (Rodaros et al., 2007). Stress and addictive drugs sensitize VTA dopaminergic neurons to the effects of excitatory inputs by common synaptic modifications (Saal et al., 2003), which can be reproduced by VTA application of CRF (Ungless et al., 2003). In the

\footnotetext{
Received 0ct. 21, 2014; revised Feb. 18, 2015; accepted Feb. 23, 2015.

Author contributions: G.N., D.M.-D., C.Q., W.R., N.-S.C., D.A., L.A.H., F.H., A.C., J.M., V.C., C.L., E.I.C., S.F., and P.J.M. designed research; G.N., D.M.-D., C.Q., A.S., K.M., W.P.R., E.M., and P.J.M. performed research; G.N., D.M.-D., C.Q., W.R., E.M., C.L., S.F., and P.J.M. analyzed data; G.N., D.M.-D., C.Q., C.L., S.F., and P.J.M. wrote the paper.

This work was supported by intramural funds of the National Institute on Drug Abuse, from Spanish Ministry of Science and Technology Grants SAF2011-23813 and SAF2009-07276, Government of Catalonia Grant 2009-SGR-12, and Center for Biomedical Research in Neurodegenerative Diseases Network Grant CB06/05/0064. P.J.M. was supported through a Ramón y Cajal Fellowship. We thank Jasmina Jiménez for technical assistance.

The authors declare no competing financial interests.

*G.N., C.Q., and D.M.D. contributed equally to this manuscript.

${ }^{\dagger}$ E.I.C., S.F., and P.J.M. are senior co-authors.

Correspondence should be addressed to either of the following: Dr. Sergi Ferré, Integrative Neurobiology Section, National Institute on Drug Abuse, Intramural Research Program, Triad Technology Building, 333 Cassell Drive, Baltimore, MD 21224, E-mail: sferre@intra.nida.nih.gov; or Dr. Peter J. McCormick, School of Pharmacy, University of East Anglia, Norwich Research Park, Norwich, NR4 7TJ, UK. E-mail: p.mccormick@uea.ac.uk.

DOI:10.1523/JNEUROSCI.4364-14.2015

Copyright $\odot 2015$ the authors $\quad 0270-6474 / 15 / 356639-15 \$ 15.00 / 0$
}

VTA of cocaine-experienced but not naive animals, stressinduced CRF release increases extracellular levels of glutamate and dopamine (Wang et al., 2005, 2007). Of the two known CRF receptors $\left(\mathrm{CRF}_{1} \mathrm{R}\right.$ and $\left.\mathrm{CRF}_{2} \mathrm{R}\right), \mathrm{CRF}_{1} \mathrm{R}$ is involved preferentially with stress-induced reinstatement of cocaine-seeking behavior and VTA dopamine release (Shaham et al., 1998; Lu et al., 2003; Lodge and Grace, 2005; Blacktop et al., 2011).

The 33- and 28-aa-long neuropeptides orexin-A (hypocretin-A) and orexin-B (hypocretin-B) are expressed within cell bodies in the lateral hypothalamus and adjacent perifornical area (Sakurai et al., 1998; de Lecea et al., 1998). These cells are the origin of an ascending arousal system that projects to the entire cortex, but apart from their well established role in arousal, orexins have a role in reward processes and substance-use disorders, which might depend on the dense orexinergic innervation of the dopaminergic cells of the VTA (Borgland et al., 2010; Mahler et al., 2014; Sakurai, 2014). A dichotomy in orexin function appears to be related to the two identified orexin receptors, with reward and arousal being associated closely with activation of $\mathrm{OX}_{1} \mathrm{R}$ and $\mathrm{OX}_{2} \mathrm{R}$, respectively (Borgland et al., 2010; Mahler et al., 2014). The orexin-hypocretin system also drives cocaine reinstatement through activation of stress pathways, which includes the participation of CRF. Thus, central administration of orexin-A led to a dose-related reinstatement of cocaine seeking, which was prevented by a nonselective CRFR antagonist, and a selective $\mathrm{OX}_{1} \mathrm{R}$ 
antagonist blocked stress-induced reinstatement of previously extinguished cocaine-seeking behavior (Boutrel et al., 2005).

The same as for CRF, VTA is a key brain area involved in the ability of the orexinergic system to promote cocaine seeking. Intra-VTA administration of orexin-A reinstated cocaine selfadministration, which was also associated with VTA glutamate and dopamine release (Wang et al., 2009). Intriguingly, although CRF and orexin-A are involved in stress-induced cocaine reinstatement by acting in the VTA, their mechanisms appeared independent (Wang et al., 2009). In the present study, we provide evidence for the existence of pharmacologically significant interactions between $\mathrm{CRF}$ and orexin- $\mathrm{A}$ that depend on $\mathrm{CRF}_{1} \mathrm{R}-\mathrm{OX}_{1} \mathrm{R}$ oligomerization. $\mathrm{CRF}_{1} \mathrm{R}-\mathrm{OX}_{1} \mathrm{R}$ heteromers are the conduits of a negative crosstalk between orexin-A and CRF observed in transfected cells and the VTA, in which they can significantly influence dendritic dopamine release. We also demonstrate that $\mathrm{CRF}_{1} \mathrm{R}-$ $\mathrm{OX}_{1} \mathrm{R}$ heteromers associate with $\sigma_{1}$ receptors $\left(\sigma_{1} \mathrm{Rs}\right)$ to form $\mathrm{CRF}_{1} \mathrm{R}-\mathrm{OX}_{1} \mathrm{R}-\sigma_{1} \mathrm{R}$ complexes and that cocaine binding to $\sigma_{1} \mathrm{R}$ in the complex promotes a long-term disruption of the orexin-ACRF negative crosstalk. Through this mechanism, cocaine sensitizes VTA cells to the excitatory effects of both CRF and orexin-A.

\section{Materials and Methods}

Ligands and HIV transactivator of transcription-linked peptides. (-)Cocaine $\mathrm{HCl}$ was purchased from Sigma and from the Spanish Agency of Medicine (number 2003C00220). $\sigma_{1}$ R ligands PD144418 (1,2,3,6tetrahydro-5-[3-(4-methylphenyl)-5-isoxazolyl]-1-propylpyridine oxalate) and PRE-084 2-(4-morpholinethyl) 1-phenylcyclohexanecarboxylate hydrochloride, CRF, orexins, SB334867 (N-(2-Methyl-6-benzoxazolyl)- $N$-1,5-naphthyridin-4-yl urea), and NBI27914 [5-chloro- $N$-(cyclopropylmethyl)-2-methyl- $N$ propyl- $N^{\prime}$-(2,4,6-trichlorophenyl)-4,6-pyrimidinediamine hydrochloride] were purchased from Tocris Bioscience. To allow intracellular delivery, a peptide or protein can be fused to the cell-penetrating HIV transactivator of transcription (TAT) peptide (YGRKKRRQRRR; Schwarze et al., 1999). HIV TAT fused to a peptide with the amino acid sequence of a transmembrane domain (TM) of a GPCR can be inserted effectively into the plasma membrane as a result of both the penetration capacity of the TAT peptide and the hydrophobic property of the TM domain (He et al., 2011). HIV TAT-fused peptides with the amino acid sequences of $\mathrm{OX}_{1} \mathrm{R}$ TM domains TM1, TM5, and TM7 were used (Genemad Synthesis). To obtain the right orientation of the inserted peptide, HIV TAT peptide was fused to the $\mathrm{C}$ terminus of $\mathrm{OX}_{1} \mathrm{R}$ TM1, TM5, and TM7 peptides, with the following final amino acid sequences: WVLIAAYVAVFLIALVGNTLVYGRKKRRQRRR, SCFFFVTYLAPLGLMGMAYFQIFYGRKKRRQRRR, and YACFTFSHWLVYANSAANPIIYNFYGRKKRRQRRR, respectively.

Expression vectors, fusion proteins, and $C R F_{1} R$ mutants. Sequences encoding amino acid residues 1-155 and 156-238 of yellow fluorescent protein (YFP) Venus protein were subcloned in pcDNA3.1 vector to obtain YFP Venus hemitruncated proteins. Human cDNAs for $\mathrm{OX}_{1} \mathrm{R}$, $\mathrm{CRF}_{1} \mathrm{R}$, ghrelin 1a receptors [growth hormone secretagogue la receptor $\left.\left(\mathrm{GHS}_{1 \mathrm{a}} \mathrm{R}\right)\right]$, or $\sigma_{1} \mathrm{R}$, cloned into pcDNA3.1, were amplified without their stop codons using sense and antisense primers harboring the following: EcoRI and KpnI sites to clone $\mathrm{CRF}_{1} \mathrm{R}, \mathrm{OX}_{1} \mathrm{R}$, or $\mathrm{GHS}_{1 \mathrm{a}} \mathrm{R}$ in pcDNA3.1RLuc vector ( $\mathrm{p} R L u c-\mathrm{N} 1$; PerkinElmer Life and Analytical Sciences) or pEYFP-N1 vector (enhanced yellow variant of GFP; Clontech), HindIII and BamHI sites to clone $\sigma_{1}$ R in pEYFP-N1 vector, or EcoRI and BamHI sites to clone $\mathrm{CRF}_{1}$ Rs and $\mathrm{OX}_{1}$ Rs in a Cherry containing vector (pcDNA3.1Cherry). Amplified fragments were subcloned to be in-frame with restriction sites of $\mathrm{p} R L u c-\mathrm{N} 1$, pEYFP-N1, or pcDNA3.1Cherry vectors to provide plasmids that express proteins fused to Renilla Luciferase (RLuc), YFP, or Cherry on the C-terminal end $\left(\mathrm{OX}_{1} \mathrm{R}-\mathrm{RLuc}, \mathrm{CRF}_{1} \mathrm{R}-\right.$ RLuc, OX $\mathrm{OX}_{1} \mathrm{R}-\mathrm{YFP}, \mathrm{CRF}_{1} \mathrm{R}-\mathrm{YFP}, \mathrm{GHS}_{1 \mathrm{a}} \mathrm{R}-\mathrm{YFP}, \sigma_{1} \mathrm{R}-\mathrm{YFP}$, or $\mathrm{CRF}_{1} \mathrm{R}-$ Cherry). Dr. Marian Castro (University of Santiago de Compostela, Santiago de Compostela, Spain) generously provided human $\beta$-arrestin 2-RLuc6 cDNA, cloned in pcDNA3.1 RLuc6 vector (pRLuc-N1; PerkinElmer Life and Analytical Sciences). For bimolecular fluorescence complementation (BiFC) experiments, human $\mathrm{cDNA}$ for $\mathrm{CRF}_{1} \mathrm{R}$ was also subcloned into pcDNA3.1-nVenus to provide a plasmid that expresses the receptor fused to the hemitruncated nYFP Venus on the C-terminal end of the receptor (CRF1R-nVenus), and human cDNA for $\mathrm{OX}_{1} \mathrm{R}$ was also subcloned into $\mathrm{pcDNA3.1-cVenus} \mathrm{to} \mathrm{provide} \mathrm{a} \mathrm{plasmid}$ that expresses the receptor fused to the hemitruncated cYFP Venus on the $\mathrm{C}$-terminal end of the receptor $\left(\mathrm{OX}_{1} \mathrm{R}\right.$-cVenus). Two $\mathrm{CRF}_{1} \mathrm{R}$ mutants were used: (1) $\mathrm{CRF}_{1} \mathrm{R} 433$, which lacks a large portion of the extracellular domain of the $\mathrm{N}$ terminus (amino acids 1-111) and is not able to

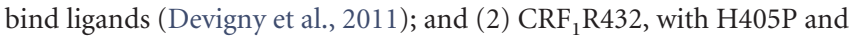
A119L mutations in the 3 IL that confer enhanced constitutive activity.

Cell clones, cell culture, and transient transfection. HEK-293T cells were grown in DMEM (Gibco) supplemented with $2 \mathrm{~mm}$ L-glutamine, 100 $\mu \mathrm{g} / \mathrm{ml}$ sodium pyruvate, $100 \mathrm{U} / \mathrm{ml}$ penicillin/streptomycin, minimal essential medium non-essential amino acids solution (1:100), and 5\% (v/v) heat-inactivated fetal bovine serum (Invitrogen) and were maintained at $37^{\circ} \mathrm{C}$ in an atmosphere with $5 \% \mathrm{CO}_{2}$. Cells were transiently transfected with the corresponding fusion protein cDNA by the polyethylenimine (Sigma) method. For receptor-heteromer signaling, $0.4 \mu \mathrm{g}$ of $\mathrm{OX}_{1} \mathrm{R}-$ RLuc cDNA and $0.3 \mu \mathrm{g}$ of $\mathrm{CRF}_{1} \mathrm{R}-\mathrm{YFP}$ cDNA were transfected, which provides $80-90 \%$ of maximum bioluminescence resonance energy transfer (BRET), as deduced from the BRET saturation curves (Fig. 1), indicating a high degree of receptor heteromerization. For the expression of $\mathrm{GHS}_{1 \mathrm{a}} \mathrm{R}-\mathrm{YFP}$, equal amounts of $\mathrm{GHS}_{1 \mathrm{a}} \mathrm{R}-\mathrm{YFP}$ and $\mathrm{GHS}_{1 \mathrm{~b}} \mathrm{R}$ cDNA were transfected to ensure $\mathrm{GHS}_{1 \mathrm{a}} \mathrm{R}$ expression at the cell membrane. HEK-293T stable cell lines expressing $\mathrm{CRF}_{1} \mathrm{R}-\mathrm{YFP}$ or $\mathrm{OX}_{1} \mathrm{R}-\mathrm{YFP}$ fusion proteins were created by transfection of the corresponding cDNA in a pcDNA3.1 plasmid. Antibiotic-resistant clones were isolated with 1000 $\mu \mathrm{g} / \mathrm{ml}$ geneticin (Invitrogen), and, after an appropriate number of passages, stable cell lines were selected and grown as above indicated in the presence of $500 \mu \mathrm{g} / \mathrm{ml}$ geneticin. Sample protein concentration was determined as a control of cell number using a Bradford assay kit (Bio-Rad) with bovine serum albumin (BSA) dilutions as standards.

Fluorescence complementation assays. HEK-293T cells were cotransfected with $0.6 \mu \mathrm{M} \mathrm{CRF}_{1} \mathrm{R}-\mathrm{nVenus} \mathrm{cDNA}$ and $0.6 \mu \mathrm{M} \mathrm{OX}_{1} \mathrm{R}-\mathrm{cVenus}$ cDNA; $48 \mathrm{~h}$ after transfection, cells were treated or not with the indicated HIV TAT-TM-fused peptides $(4 \mu \mathrm{M})$ for $60 \mathrm{~min}$ at $37^{\circ} \mathrm{C}$. To quantify protein-reconstituted YFP Venus expression, cells $(20 \mu \mathrm{g}$ of protein) were distributed in 96-well microplates (black plates with a transparent bottom; Porvair), and fluorescence was read in a Fluo Star Optima Fluorimeter (BMG Labtech) equipped with a high-energy xenon flash lamp, using a $10 \mathrm{~nm}$ bandwidth excitation filter at $400 \mathrm{~nm}$ reading. Protein fluorescence expression was determined as fluorescence of the sample minus the fluorescence of cells not expressing the fusion proteins.

Resonance energy transfer experiments. For BRET assays, HEK-293T cells were transiently cotransfected with a constant amount of cDNA encoding for proteins fused to RLuc and with increasing amounts of the cDNA corresponding to proteins fused to YFP. To quantify protein YFP expression, cells ( $20 \mu \mathrm{g}$ of protein) were distributed in 96-well microplates (black plates with a transparent bottom), and fluorescence was read in the Fluo Star Optima Fluorimeter using a $10 \mathrm{~nm}$ bandwidth excitation filter at $400 \mathrm{~nm}$ reading. Protein fluorescence expression was determined as fluorescence of the sample minus the fluorescence of cells expressing the BRET donor alone. For BRET measurements, the equivalent of $20 \mu \mathrm{g}$ of cell suspension were distributed in 96-well microplates (Corning 3600, white plates; Sigma), and coelenterazine H ( $5 \mu \mathrm{M}$; Invitrogen) was added. After $1 \mathrm{~min}$, readings were obtained using a Mithras LB 940 (Berthold Technologies) that allows the integration of the signals detected in the short-wavelength filter at $485 \mathrm{~nm}$ and the longwavelength filter at $530 \mathrm{~nm}$. To quantify protein RLuc expression luminescence, readings were also performed $10 \mathrm{~min}$ after addition of coelenterazine $\mathrm{H}(5 \mu \mathrm{M})$. For sequential resonance energy transfer (SRET) assays, HEK-293T cells were transiently cotransfected with constant amounts of cDNAs encoding for both receptor fused to RLuc and YFP proteins and with increasingly amounts of cDNA corresponding to the receptor fused to Cherry protein. After $48 \mathrm{~h}$ of transfection, quantifications were performed in parallel in aliquots of transfected cells $(20 \mu \mathrm{g}$ of protein): (1) quantification of receptor YFP or receptor RLuc expression was performed as indicated for BRET experiments; (2) for quanti- 
A

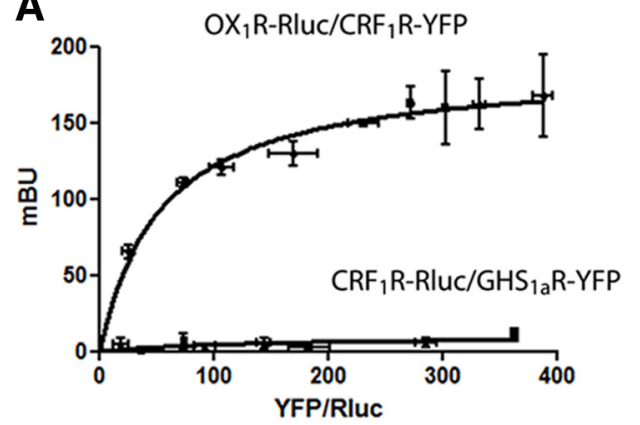

C
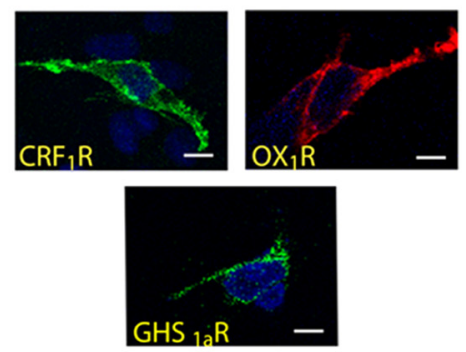

B
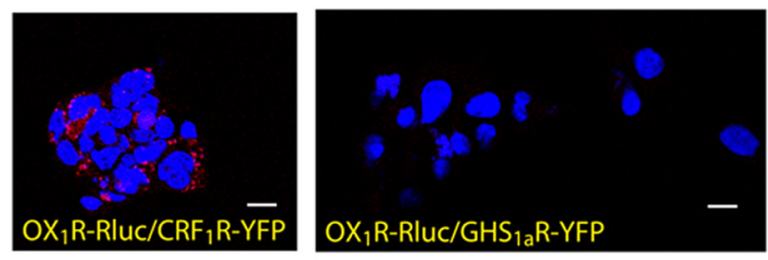

D

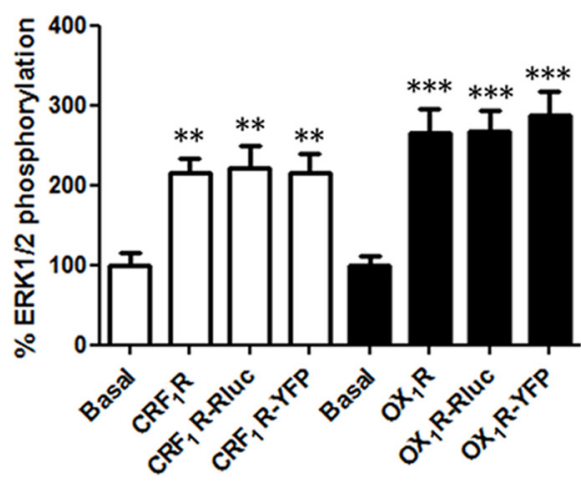

P-ERK1/2

Total-ERK1/2

Figure 1. $\quad C_{1} F_{1} R-0 X_{1} R$ heteromers in transfected HEK-293T cells. $A$, BRET saturation experiments in cells transfected with $0 X_{1} R-R L$ Luc cDNA $(0.4 \mu g)$ and increasing amounts of CRF $R$ - $\mathrm{YFP}$ cDNA $(0.05-0.5 \mu \mathrm{g})$. Low and linear BRET is observed in cells transfected with $0 \mathrm{X}_{1} \mathrm{R}-\mathrm{RLuc} \mathrm{CDNA}(0.4 \mu \mathrm{g})$ and GHS ${ }_{1 \mathrm{a}} \mathrm{R}-\mathrm{YFP}$ CDNA $(0.4-2 \mu \mathrm{g})$. BRET, expressed as mBU, is given as a function of $1000 \times$ ratio of fluorescence of the acceptor (YFP) and Luciferase activity of the donor (Rluc). Values are means \pm SEMs of six to seven replications of one independent experiment per point. $B$, Confocal microscopy images (superimposed sections) from PLA experiments performed in HEK-293T cells transfected with CRF R-YFP cDNA (0.3 $\mu \mathrm{g})$ and OX $\mathrm{X}_{1} \mathrm{R}-\mathrm{RLuc} \mathrm{CDNA}_{1}(0.4 \mu \mathrm{g})$ (left) or GHS ${ }_{1 \mathrm{a}} \mathrm{R}-\mathrm{YFP}$ CDNA $(2 \mu \mathrm{g})$ and $0 X_{1} R-R L u c C D N A(0.4 \mu \mathrm{g})$ (right). Heteromeric complexes appear as red spots and cell nuclei in blue (DAPI stained). Scale bars, $20 \mu \mathrm{m}$. C, Confocal microscopy images of HEK-293T cells transfected with CRF $R-Y F P$ CDNA $\left(0.3 \mu\right.$; l left), OX $\mathrm{X}_{1} \mathrm{R}-\mathrm{RLuc}$ CDNA $\left(0.4 \mu \mathrm{g}\right.$; middle), or $\mathrm{GSH}_{1 \mathrm{a}} \mathrm{R}-\mathrm{YFP}$ (2 $\mu \mathrm{g}$; right). YFP-fused receptors are identified by their own fluorescence (green) and OX $R$ R-RLuc by immunocytochemistry (red). Scale bars, $10 \mu \mathrm{m}$. D, ERK1/2 phosphorylation in HEK-293T cells transfected with CRF $R_{1}$, CRF $R$-RLuc, or CRF, R-YFP cDNA (0.3 $\mu$ g; white columns) or with $0 X_{1} R, O X_{1} R-R L u c$, or $0 X_{1} R-Y F P c D N A(0.4 \mu$; black columns) were treated with CRF (100 nm) or orexin- $A(50 \mathrm{~nm})$, respectively. Values are means \pm SEMs of seven experiments per group and are expressed as percentage of basal levels (100\%). One-way ANOVA followed by Bonferroni's multiple comparison post hoc test shows significant agonist effect versus basal values $(* * p<0.01$ and $\left.{ }^{* * *} p<0.001\right)$. Representative Western blots are at the bottom.

fication of receptor Cherry expression, cells were distributed in 96-well microplates (Corning black plates with a transparent bottom), and fluorescence was read in the Fluo Star Optima Fluorimeter using a $10 \mathrm{~nm}$ bandwidth excitation filter at 590-nm reading; and (3) for quantification of SRET, cells were distributed in 96-well microplates (black plates with a transparent bottom), and coelenterazine $\mathrm{H}(5 \mu \mathrm{M})$ was added. After 1 min, the readings were collected using a using a Fluo Star Optima Fluorimeter that allows the integration of the signals detected in the shortwavelength filter at $530 \mathrm{~nm}$ and the long-wavelength filter at $590 \mathrm{~nm}$. Net BRET and net SRET were defined as [(long-wavelength emission)/ (short-wavelength emission)] - Cf, where Cf corresponds to [(longwavelength emission)/(short-wavelength emission)] for the donor construct expressed alone in the same experiment. Both fluorescence and luminescence of each sample were measured before every experiment to confirm similar donor expressions $(\sim 100,000$ bioluminescence units) while monitoring the increase in acceptor expression (1000-40,000 fluorescence units). BRET or SRET was expressed as milliBRET (mBU) or milliSRET $(\mathrm{mSU})$ units (net BRET or SRET $\times 1000)$. Data were fitted to a nonlinear regression equation, assuming a single-phase saturation curve with GraphPad Prism software (GraphPad Software). The relative amount of BRET or SRET is given as a function of $100 \times$ the ratio between the fluorescence of the acceptor (YFP or Cherry) and the Luciferase activity of the donor (RLuc).

Proximity ligation assay. For proximity ligation assays (PLAs), transfected cells were grown on glass coverslips and were fixed in $4 \%$ paraformaldehyde for $15 \mathrm{~min}$, washed with PBS containing $20 \mathrm{~mm}$ glycine, permeabilized with the same buffer containing $0.05 \%$ Triton X-100, and washed successively with PBS. Heteromers were detected using the Duolink II in situ PLA detection Kit (OLink Bioscience) following the instructions of the supplier. To detect both $\mathrm{OX}_{1} \mathrm{R}-\mathrm{RLuc}-\mathrm{CRF}_{1} \mathrm{R}-\mathrm{YFP}$ and $\mathrm{OX}_{1} \mathrm{R}-\mathrm{RLuc}-\mathrm{GHS}_{1 \mathrm{a}} \mathrm{R}-\mathrm{YFP}$ heteromers, a mixture of equal amounts of rabbit anti-RLuc antibody (EMD Millipore) and mouse anti-YFP antibody (Santa Cruz Biotechnology) was used and incubated with antirabbit plus and anti-mouse minus PLA probes. Cells were mounted using the mounting medium with DAPI. The samples were observed in a Leica SP2 confocal microscope equipped with an apochromatic $63 \times$ oilimmersion objective (numerical aperture 1.4) and 405 and $561 \mathrm{~nm}$ laser lines. For each field of view, a stack of two channels (one per staining) and $9-15 \mathrm{Z}$ stacks with a step size of $1 \mu \mathrm{m}$ were acquired. Images were opened and processed with NIH Image J confocal.

Immunocytochemistry. Cells were fixed in 4\% paraformaldehyde for 15 min and washed with PBS containing $20 \mathrm{~mm}$ glycine (buffer A) to quench the aldehyde groups. After permeabilization with buffer A containing $0.2 \%$ Triton X-100 for 5 min, cells were treated with PBS containing $1 \%$ BSA. After $1 \mathrm{~h}$ at room temperature, cells were labeled with the primary mouse monoclonal anti-RLuc receptor antibody (1:200; Millipore) for $1 \mathrm{~h}$ to detect $\mathrm{OX}_{1} \mathrm{R}-\mathrm{RLuc}$, washed, and stained with the secondary Cy3 donkey anti-mouse antibody (1:200; Jackson ImmunoResearch). $\mathrm{CRF}_{1} \mathrm{R}$ fused to YFP protein were detected by their fluorescence properties. The samples were rinsed several times and mounted with a medium suitable for immunofluorescence (30\% Mowiol; Calbiochem). Samples were observed in a Leica SP2 confocal microscope.

Rat VTA slices. Male Sprague Dawley rats (2 months old; animal facility of the Faculty of Biology, University of Barcelona) were used. The 
animals were housed two per cage and kept on a $12 \mathrm{~h}$ dark/light cycle with food and water available ad libitum, and experiments were performed during the light cycle. All procedures were approved by the Catalan Ethical Committee for Animal Use (CEAA/DMAH 4049 and 5664). Animals were killed by decapitation under $4 \%$ isoflurane anesthesia, and brains were rapidly removed, placed in ice-cold oxygenated $\left(\mathrm{O}_{2} / \mathrm{CO}_{2}, 95 \% / 5 \%\right)$ Krebs- $\mathrm{HCO}_{3}^{-}$buffer (in mM: $124 \mathrm{NaCl}, 4 \mathrm{KCl}, 1.25 \mathrm{KH}_{2} \mathrm{PO}_{4}, 1.5 \mathrm{MgCl}_{2}$, $1.5 \mathrm{CaCl}_{2}, 10$ glucose, and $26 \mathrm{NaHCO}_{3}, \mathrm{pH} 7.4$ ), and sliced at $4^{\circ} \mathrm{C}$ using a brain matrix (Zivic Instruments). VTA slices (500 $\mu \mathrm{m}$ thick) were kept at $4^{\circ} \mathrm{C}$ in Krebs $-\mathrm{HCO}_{3}^{-}$buffer during the dissection; each slice was transferred into a 12-well plate with Corning Netwell inserts, containing $2 \mathrm{ml}$ of ice-cold Krebs- $\mathrm{HCO}_{3}^{-}$buffer. The temperature was raised to $23^{\circ} \mathrm{C}$, and, after $30 \mathrm{~min}$, the medium was replaced by $2 \mathrm{ml}$ of fresh Krebs$\mathrm{HCO}_{3}^{-}$buffer $\left(23^{\circ} \mathrm{C}\right)$. Slices were incubated under constant oxygenation $\left(\mathrm{O}_{2} / \mathrm{CO}_{2}, 95 \% / 5 \%\right)$ at $30^{\circ} \mathrm{C}$ for $4 \mathrm{~h}$ in an Eppendorf Thermomixer $(5$ Prime), and the medium was replaced by fresh Krebs- $\mathrm{HCO}_{3}^{-}$buffer and incubated for $30 \mathrm{~min}$ before the addition of any agent. After incubation, the solution was discarded, and slices were frozen on dry ice and stored at $-80^{\circ} \mathrm{C}$ until ERK1/2 phosphorylation was determined.

Akt and ERK1/2 phosphorylation. Cells or rat VTA slices were treated or not with the indicated ligands for the indicated time and were lysed by the addition of $300 \mu \mathrm{l}$ of ice-cold lysis buffer ( $50 \mathrm{~mm}$ Tris-HCl, $\mathrm{pH}$ 7.4, 50 $\mathrm{mm} \mathrm{NaF}, 150 \mathrm{~mm} \mathrm{NaCl}, 45 \mathrm{~mm} \beta$-glycerophosphate, $1 \%$ Triton X-100, 20 $\mu \mathrm{M}$ phenyl-arsine oxide, $0.4 \mathrm{~mm} \mathrm{NaVO}_{4}$, and protease inhibitor mixture). Cellular debris was removed by centrifugation at $13,000 \times g$ for 5 $\min$ at $4^{\circ} \mathrm{C}$, and the protein was quantified by the bicinchoninic acid method using BSA dilutions as standard. Akt or ERK1/2 phosphorylation was then determined by Western blot as described previously (Moreno et al., 2014), using a rabbit anti-phospho-Ser473 Akt antibody (1:2500; Signalway Antibody) for Akt phosphorylation or mouse anti-phosphoERK1/2 antibody (1:2500; Sigma) and rabbit anti-ERK1/2 antibody that recognizes both phosphorylated and nonphosphorylated ERK1/2 (1: 40,000; Sigma).

$\beta$-Arrestin 2 recruitment. Arrestin recruitment was determined as described previously (Moreno et al., 2014). Briefly, BRET experiments were performed in HEK-293T cells $48 \mathrm{~h}$ after transfection with the cDNA corresponding to the indicated receptors fused or not to the YFP and $\beta$-arrestin 2-RLuc cDNA $(0.5 \mu \mathrm{g})$. Cells ( $20 \mu \mathrm{g}$ protein) were distributed in 96-well microplates (Corning 3600, white plates with white bottom; Sigma) and were incubated with the indicated antagonist for $10 \mathrm{~min}$ and stimulated with the agonist for $10 \mathrm{~min}$ before the addition of coelenterazine $\mathrm{H}$ ( $5 \mu \mathrm{M}$; Invitrogen). After 1 min of adding coelenterazine H, BRET between $\beta$-arrestin $2-$ RLuc and receptor YFP was determined and quantified as described above.

cAMP production. Transfected HEK-293T cells were incubated in serumfree medium for $16 \mathrm{~h}$ before the experiment. Cells were preincubated for 15 min at $37^{\circ} \mathrm{C}$ with zardaverine (50 $\mu \mathrm{M}$; Tocris Bioscience) and treated for 15 min with the indicated concentration of agonists in the presence or absence of forskolin ( $0.5 \mu \mathrm{M}$; Sigma). When indicated, receptor antagonists were preincubated $10 \mathrm{~min}$ before agonist addition. To stop the reaction, cells were placed on ice, washed with ice-cold PBS, and centrifuged at $2500 \times g$ for 5 min at $4^{\circ} \mathrm{C}$. The pellet was washed with ice-cold HBSS with $10 \mathrm{~mm}$ glucose and resuspended with $200 \mu \mathrm{l}$ of $\mathrm{HClO}_{4}(4 \%)$ for $30 \mathrm{~min}$, and $1.5 \mathrm{M} \mathrm{KOH}$ was added to reach neutral $\mathrm{pH}$. Samples were centrifuged at $15,000 \times \mathrm{g}$ for 30 $\min$ at $4^{\circ} \mathrm{C}$, and the supernatant was frozen at $-20^{\circ} \mathrm{C}$. Accumulation of cAMP was measured with Cyclic AMP $\left({ }^{3} \mathrm{H}\right)$ Assay System (GE Healthcare) as described by the manufacturer.

Dynamic mass redistribution assays. Dynamic mass redistribution (DMR) was determined using an EnSpire Multimode Plate Reader (PerkinElmer Life and Analytical Sciences). Refractive waveguide grating optical biosensors, integrated in 384-well microplates, allow extremely sensitive measurements of changes in local optical density in a detecting zone up to $150 \mathrm{~nm}$ above the surface of the sensor. Cellular mass movements induced during receptor activation were detected by illuminating the underside of the biosensor with polychromatic light and measured as changes in wavelength of the reflected monochromatic light that is a sensitive function of the index of refraction. The magnitude of this wavelength shift (in picometers) is directly proportional to the amount of DMR. Briefly, $24 \mathrm{~h}$ before the assay, cells were seeded at a density of 5000 cells per well in 384-well sensor microplates with
$30 \mu \mathrm{l}$ of growth medium and cultured for $24 \mathrm{~h}\left(37^{\circ} \mathrm{C}, 5 \% \mathrm{CO}_{2}\right)$ to obtain $70-80 \%$ confluent monolayers. Cells were washed twice with assay buffer (HBSS with $20 \mathrm{~mm}$ HEPES, pH 7.15) and incubated $2 \mathrm{~h}$ in $40 \mu \mathrm{l} /$ well assay buffer with $0.1 \% \mathrm{DMSO}$ at $24^{\circ} \mathrm{C}$, the sensor plate was scanned, and a baseline optical signature was recorded before incubating the indicated antagonists for $30 \mathrm{~min}$ and adding $10 \mu \mathrm{l}$ of agonist dissolved in assay buffer containing $0.1 \%$ DMSO. DMR responses were monitored for at least 8000 s. Kinetic results were analyzed using EnSpire Workstation Software version 4.10 (EnSpire Software), and curves were normalized with respect to the baseline.

In vivo VTA dendritic dopamine release. Male Sprague Dawley rats (3 months old; Charles River Laboratories) were used. Animals were housed two per cage and kept on a $12 \mathrm{~h}$ dark/light cycle with food and water available ad libitum. Experiments were performed during the light cycle. All animals used in the study were maintained in accordance with the guidelines of National Institutes of Health animal care, and the animal research conducted to perform this study was reviewed and approved by the National Institute on Drug Abuse Intramural Research Program Animal Care and Use Committee (Protocol 12-BNRB-73). Rats were deeply anesthetized with $3 \mathrm{ml} / \mathrm{kg}$ Equithesin [4.44 g of chloral hydrate, $0.972 \mathrm{~g}$ of Na pentobarbital, $2.124 \mathrm{~g}$ of $\mathrm{MgSO}_{4}, 44.4 \mathrm{ml}$ of propylene glycol, $12 \mathrm{ml}$ of ethanol, and distilled $\mathrm{H}_{2} \mathrm{O}$ up to $100 \mathrm{ml}$ of final solution (National Institute on Drug Abuse Pharmacy)] and implanted unilaterally in the VTA (coordinates in $\mathrm{mm}$ from bregma with a $10^{\circ}$ angle in the coronal plane: anterior, 5.6; lateral, 2.4; vertical, 9) with a specially designed microdialysis probe that allows the direct infusion of large peptides within the sampling area. After surgery, rats were allowed to recover in hemispherical CMA-120 cages (CMA Microdialysis) equipped with two-channel overhead fluid swivels (Instech) connected to a sample collector (CMA 470; CMA). Twenty-four hours after implanting the probe, in the middle of the light period of the light/dark cycle, experiments were performed on freely moving rats in the same hemispherical home cages in which they recovered overnight from surgery. An ACSF (in mm: $144 \mathrm{NaCl}, 4.8 \mathrm{KCl}, 1.7 \mathrm{CaCl}_{2}$, and $1.2 \mathrm{MgCl}_{2}$ ) was pumped through the probe at a constant rate of 1 $\mu \mathrm{l} / \mathrm{min}$. After a washout period of $90 \mathrm{~min}$, dialysate samples were collected at $20 \mathrm{~min}$ intervals. For peptide infusion, orexins and CRF were dissolved in ACSF to a final concentration of $10 \mu \mathrm{M}$, whereas HIV TAT-fused peptides were dissolved in $0.1 \%$ DMSO in ACSF to a final concentration of $30 \mu \mathrm{M}$ (TM1 and TM5) or $60 \mu \mathrm{M}$ (TM7). All peptides were injected with a $1 \mu \mathrm{l}$ syringe (Hamilton) driven by an infusion pump and coupled with silica tubing ( $73 \mu \mathrm{m}$ inner diameter; Polymicro) to the microdialysis probe infusion port (dead volume, 40 $\mathrm{nl}$ ), which was primed with ACSF and plugged during implantation. All peptides were delivered at a rate of $16.6 \mathrm{nl} / \mathrm{min}$. The $\mathrm{OX}_{1} \mathrm{R}$ antagonist SB334667 was dissolved in sterile saline and administered intraperitoneally $(10 \mathrm{mg} / \mathrm{kg}) 40 \mathrm{~min}$ before peptide infusion. The $\mathrm{CRF}_{1} \mathrm{R}$ antagonist NBI27914 was dissolved in 5\% DMSO in water and administered intraperitoneally $(10 \mathrm{mg} / \mathrm{kg}) 40 \mathrm{~min}$ before peptide infusion. The $\sigma_{1}$ R agonist PRE-084 was dissolved in ACSF at a concentration of $100 \mu \mathrm{M}$ and was perfused through the microdialysis probe (reverse dialysis). Cocaine $\mathrm{HCl}$ was administered intraperitoneally $24 \mathrm{~h}$ before the start of the microdialysis experiment at a dose of $15 \mathrm{mg} / \mathrm{kg}$. At the end of the experiment, rats were given an overdose of Equithesin, the brains were extracted and fixed in formaldehyde, and probe placement was verified using cresyl violet staining. Dopamine content was measured by HPLC coupled with a coulometric detector (5200a Coulochem III; ESA).

Statistics. Sample sizes were between 5 and 10, which our previous published work indicated are sufficient to perform appropriate statistical analysis. Parametric statistics (unpaired $t$ test and one-way or repeatedmeasures ANOVA) were used, because the different groups analyzed showed normality and homogeneity of variance. GraphPad Prism software version 5 was used for the statistical analysis.

\section{Results}

Expression and functional characterization of heteromers between $O X_{1} R$ and $C R F_{1} R$ in transfected cells

BRET and PLA experiments were performed in HEK-293T cells transfected with $\mathrm{OX}_{1} \mathrm{R}-\mathrm{RLuc}$ and $\mathrm{CRF}_{1} \mathrm{R}-\mathrm{YFP}$ (Figs. $1 A, B$ ). 
A

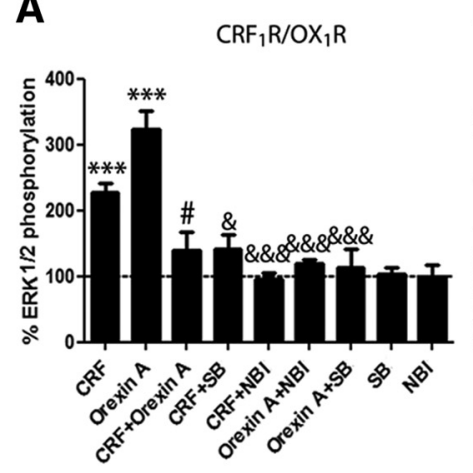

\section{D}

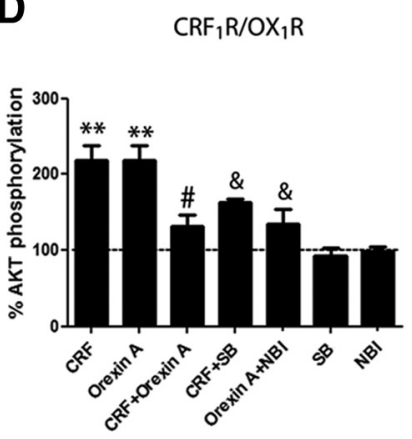

G
B

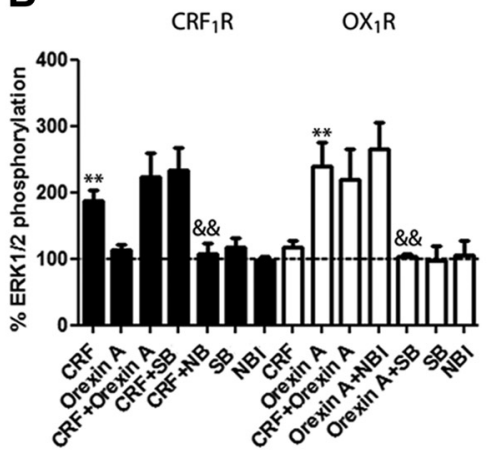

E

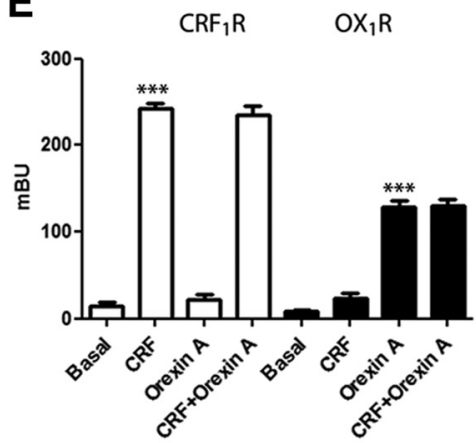

C $\mathrm{CRF}_{1} \mathrm{R} / \mathrm{OX} \mathrm{X}_{1} \mathrm{R}$

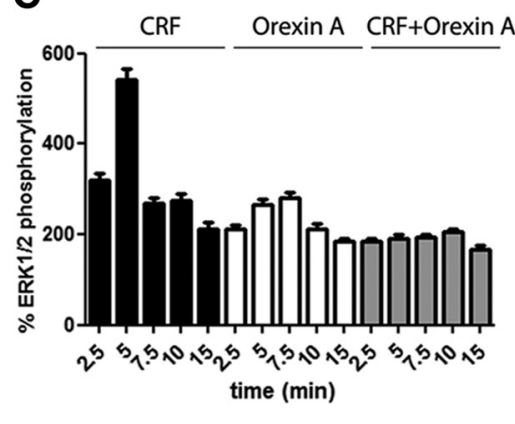

$\mathbf{F}$

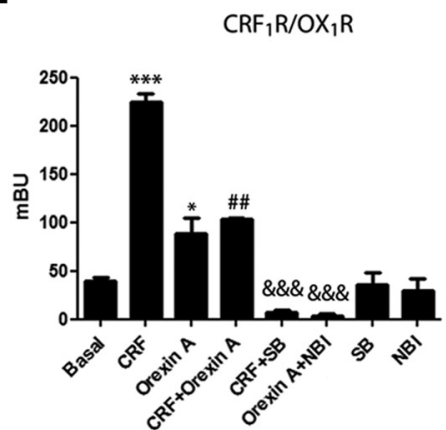

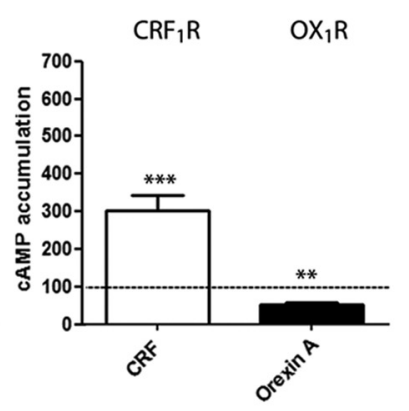

H

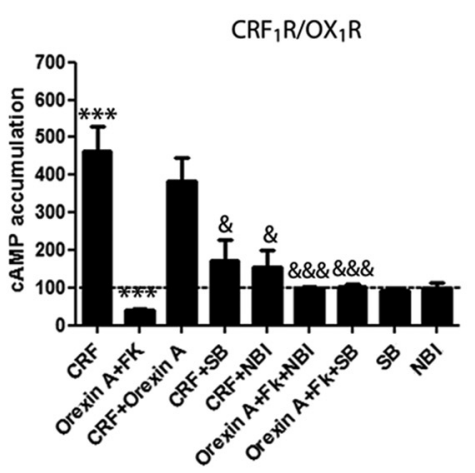

Figure 2. $\quad C R F_{1} R-0 X_{1} R$ heteromer function in transfected HEK-293T cells. $A-C$, ERK1/2 phosphorylation was performed in cells transfected with CRF $R-Y F P$ $D N A(0.3 \mu$ g; $B)$ or $0 X_{1} R-R L$ Luc CDNA $(0.4 \mu \mathrm{g} ; \boldsymbol{B})$ or both $(\boldsymbol{A}, \boldsymbol{C})$ pretreated (10 min) with vehicle, the $0 \mathrm{X}_{1} \mathrm{R}$ antagonist SB334667 (SB; $\left.1 \mu \mathrm{m}\right)$, or the CRF $\mathrm{R}_{1}$ antagonist NBI27914 (NBl; $\left.1 \mu \mathrm{M}\right)$, followed by treatment with medium, CRF (100 $\mathrm{nm})$, orexin- $\mathrm{A}(50 \mathrm{~nm})$, or both for $7 \mathrm{~min}(\boldsymbol{A}, \boldsymbol{B})$ or for $2.5,5,7.5,19$, and $15 \mathrm{~min}$ (C). Values are means \pm SEMs of five to six experiments per group and are expressed as percentage of basal levels (100\%; dotted line). D, Akt phosphorylation was determined in cells transfected with CRF $_{1} R-Y F P$ cDNA $(0.3 \mu \mathrm{g})$ and $0 X_{1} R-R L u c$ CDNA $(0.4 \mu \mathrm{g})$, pretreated (10 min) with vehicle, the $0 X_{1} R$ antagonist

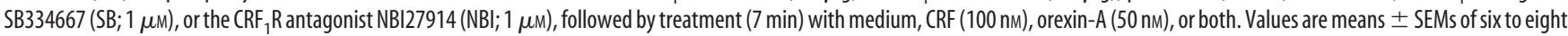
experiments per treatment and are expressed as percentage of basal levels (100\%; dotted line). $\boldsymbol{E}, \boldsymbol{F}, \beta$-Arrestin 2 recruitment measured by BRET in cells transfected with CRF $R$-YFP cDNA (0.3 $\mu$; $\boldsymbol{E}$, white bars) or OX 1 R-YFP cDNA $(0.4 \mu \mathrm{g} ; \boldsymbol{E}$, black bars), or both $(\boldsymbol{F})$ and $\beta$-arrestin 2-RLuc cDNA $(0.5 \mu \mathrm{g})$. Cells were pretreated (10 min) with vehicle, SB334667 (SB; $1 \mu \mathrm{m})$, or NBI27914 (NBI; 1 $\mu \mathrm{M})$, followed by treatment $(7 \mathrm{~min})$ with $(\mathrm{RF}(100 \mathrm{nM})$, orexin-A $(50 \mathrm{~nm})$, or both. Values are means \pm SEMs of five to six experiments per treatment. $G, H$, cAMP accumulation was determined in cells transfected with CRF $R-Y F P$ cDNA $\left(0.3 \mu \mathrm{g} ; \boldsymbol{G}\right.$, white bar) or OX $\mathrm{R}$ R-RLuc CDNA $\left(0.4 \mu \mathrm{g} ; \boldsymbol{G}\right.$, black bar), or both $(\boldsymbol{H})$ ). Cells were pretreated (10 min) with vehicle, the $0 \mathrm{X}_{1} \mathrm{R}$ antagonist SB334667 $(\mathrm{SB} ; 1 \mu \mathrm{M})$, or the $\mathrm{CRF}_{1}$ Rantagonist NBI27914 (NBI; $\left.1 \mu \mathrm{M}\right)$, followed by treatment $(7 \mathrm{~min})$ with medium, CRF (100 nM), orexin-A ( $\left.50 \mathrm{~nm}\right)$, or both. Values are means \pm SEMs of six to eight experiments per treatment and expressed as increases of basal levels or as decreases of forskolin-induced cAMP accumulation (for orexin- $A$; $100 \%$; dotted line). In $A, B, D-F$, and $\boldsymbol{H}$, One-way ANOVA followed by Bonferroni's multiple comparison post hoc test shows significant single agonist effect versus basal values ( ${ }^{*} p<0.05,{ }^{* *} p<0.01$, and ${ }^{* * *} p<0.001$ ), or CRF plus orexin-A treatment versus CRF or orexin-A treatment ( ${ }^{\#} p<0.05$ ) or antagonist plus agonist versus agonist with or without forskolin (FK; ${ }^{\&} p<0.05,{ }^{\& \&} p<0.01$, and ${ }^{\& \& \&} p<0.001$ ). In G, unpaired Student's $t$ test (two-tailed) shows significant difference of single agonist treatment versus basal values $\left({ }^{* *} p<0.01\right.$ and $\left.{ }^{* * *} p<0.001\right)$.

These fusion proteins properly trafficked to the cell membrane, as shown by confocal microscopy (Fig. 1C), and were functional, as shown by comparing their ability to increase ERK1/2 phosphorylation with that of native receptors (Fig. 1D). BRET saturation curves were obtained in cells expressing $\mathrm{OX}_{1} \mathrm{R}-\mathrm{RLuc}$ and increasing amounts of $\mathrm{CRF}_{1} \mathrm{R}-\mathrm{YFP}$ (Fig. 1A), with BRET max $_{\text {ax }}$ of $186 \pm 6 \mathrm{mBU}$ and $\mathrm{BRET}_{50}$ of $54 \pm 7$, indicating that these receptors can indeed form heteromers. As a negative control, a low and linear BRET was detected in cells expressing $\mathrm{CRF}_{1} \mathrm{R}-\mathrm{RLuc}$ and increasing amounts of $\mathrm{GHS}_{1 \mathrm{a}} \mathrm{R}$ fused to YFP (Fig. 1A). Accordingly, receptor heteromers were also visualized as red spots by using PLA in cells expressing $\mathrm{OX}_{1} \mathrm{R}-\mathrm{RLuc}$ and $\mathrm{CRF}_{1} \mathrm{R}-\mathrm{YFP}$ but not in cells expressing CRF $_{1}$ R-RLuc and GHSR $_{1 a}-\mathrm{YFP}$ (Fig. $1 B$ ).

$\mathrm{CRF}$ or the $\mathrm{OX}_{1} \mathrm{R}$ agonist orexin-A induced ERK1/2 phosphorylation in cells coexpressing $\mathrm{CRF}_{1} \mathrm{R}$ and $\mathrm{OX}_{1} \mathrm{R}$ (Fig. $2 A$ ). Orexin-A-induced signaling was inhibited by the $\mathrm{OX}_{1} \mathrm{R}$ antago- 
nist SB334867 and the $\mathrm{CRF}_{1} \mathrm{R}$ antagonist NBI27914, that did not modify basal levels by themselves, and vice versa, CRFinduced ERK1/2 phosphorylation was antagonized by both NBI27914 and SB334667. Thus, $\mathrm{CRF}_{1} \mathrm{R}-\mathrm{OX}_{1} \mathrm{R}$ heteromers display cross-antagonism, a property seen in previous receptor heteromers (Guitart et al., 2014; Moreno et al., 2014). A negative crosstalk was also observed because ERK1/2 phosphorylation during coactivation of both receptors was significantly lower compared with that induced by single activation of either $\mathrm{CRF}_{1} \mathrm{R}$ or $\mathrm{OX}_{1} \mathrm{R}$ (Fig. 2A). Cross-antagonism and negative crosstalk were not attributable to either the lack of ligand specificity, because they were not observed in cells expressing single receptors (Fig. $2 B$ ), or a change in the shape of the time-response curve of ERK1/2 phosphorylation (Fig. 2C). Negative crosstalk and cross-antagonism were also observed at the level of Akt phosphorylation (Fig. $2 D$ ). $\beta$-Arrestin recruitment was also analyzed, because it has been shown to mediate ERK1/2 and Akt phosphorylation for several GPCRs (Kovacs et al., 2009). Orexin-A but not CRF significantly increased control BRET values in cells expressing $\beta$-arrestin 2-RLuc and $\mathrm{OX}_{1} \mathrm{R}-\mathrm{YFP}$. Similarly, CRF but not orexin-A increased BRET values in cells expressing $\beta$-arrestin $2-$ RLuc and $\mathrm{CRF}_{1}$ R-YFP (Fig. $2 E$ ), indicating both the specificity of the ligands and the ability of these receptors to recruit $\beta$-arrestin 2 when activated. Significantly, not only CRF but also orexin-A significantly increased BRET values in cells expressing $\beta$-arrestin 2-RLuc, $\mathrm{CRF}_{1} \mathrm{R}-\mathrm{YFP}$, and $\mathrm{OX}_{1} \mathrm{R}$ (Fig. 2F). During coactivation with both agonists $\mathrm{CRF}$ and orexin-A, a negative crosstalk was observed at the level of $\beta$-arrestin 2 recruitment. Furthermore, cross-antagonism could also be demonstrated, and CRF-promoted and orexin-Apromoted $\beta$-arrestin 2 recruitment were counteracted by SB334867 and NBI27914, respectively (Fig. $2 F$ ).

Orexin-A decreased forskolin-stimulated cAMP in cells expressing $\mathrm{OX}_{1} \mathrm{R}$, indicating receptor coupling to a $\mathrm{G}_{\mathrm{i}}$-protein, and CRF promoted an increase in cAMP production in cells expressing $\mathrm{CRF}_{1} \mathrm{R}$, indicating receptor coupling to a $\mathrm{G}_{\mathrm{s}}$-protein (Fig. $2 G$ ). The same findings were observed in cells coexpressing $\mathrm{OX}_{1} \mathrm{R}$ and $\mathrm{CRF}_{1} \mathrm{R}$, suggesting that the receptors can signal independently through their preferred G-proteins in the $\mathrm{CRF}_{1} \mathrm{R}-\mathrm{OX}_{1} \mathrm{R}$ heteromer (Fig. $2 \mathrm{H}$ ). Crossantagonism could also be observed at the adenylyl-cyclase level in cells coexpressing $\mathrm{OX}_{1} \mathrm{R}$ and $\mathrm{CRF}_{1} \mathrm{R}$. Thus, orexin-A-induced inhibition of forskolin-stimulated cAMP accumulation was counteracted not only by the $\mathrm{OX}_{1} \mathrm{R}$ antagonist SB334867 but also by the $\mathrm{CRF}_{1} \mathrm{R}$ antagonist NBI27914. Equally, CRF-induced cAMP accumulation was counteracted by both NBI27914 and
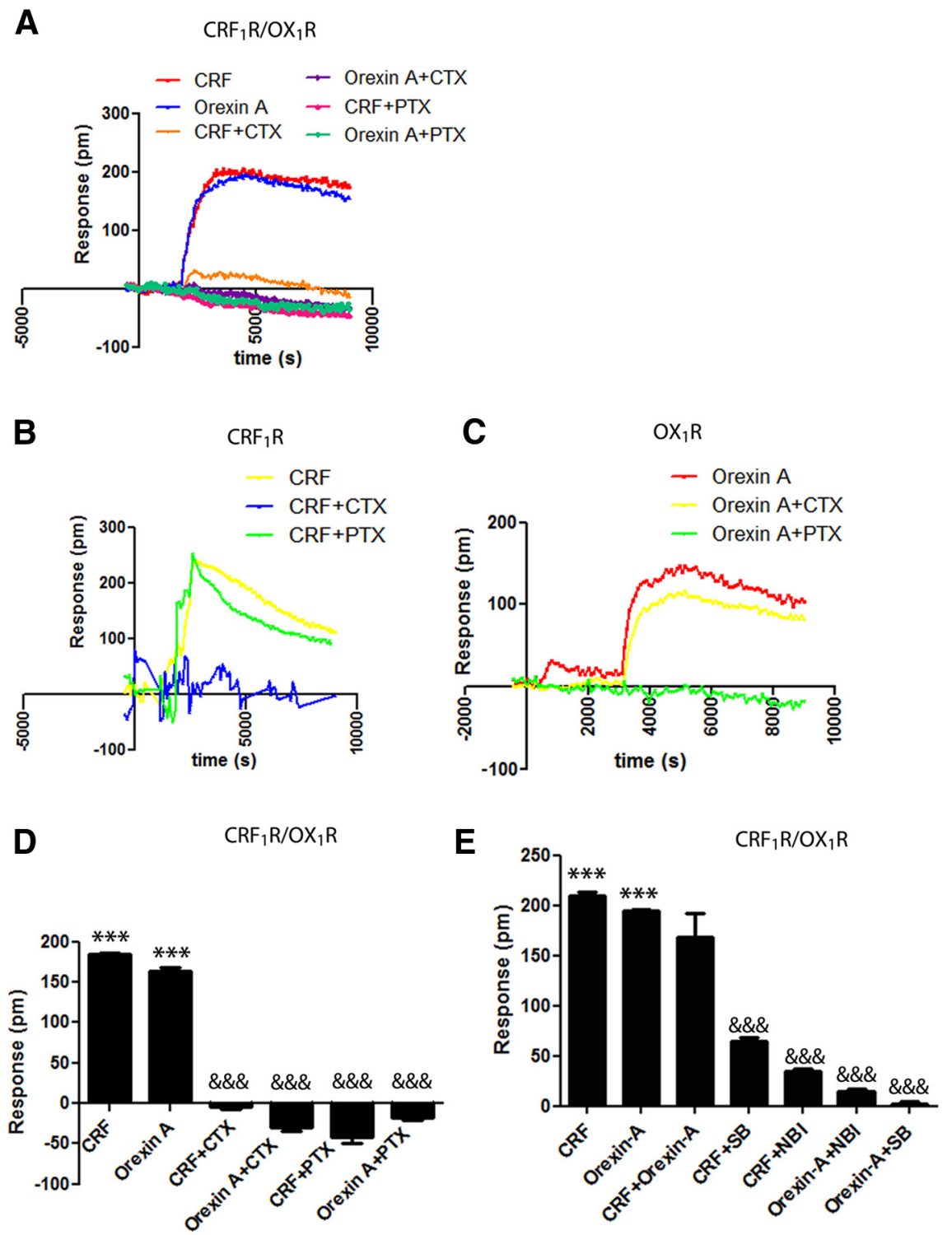

Figure 3. $\quad \mathrm{CRF}_{1} \mathrm{R}-\mathrm{O} \mathrm{X}_{1} \mathrm{R}$ heteromer signaling detected by DMR. DMR was determined in HEK-293T cells stably transfected with $0 X_{1} R$ and transiently transfected with $\mathrm{CRF}_{1} \mathrm{R} C \mathrm{CDN}(0.3 \mu \mathrm{g} ; \boldsymbol{A}, \boldsymbol{D}, \boldsymbol{E})$ or only stably transfected with $\mathrm{OX} \mathrm{X}_{1} \mathrm{R}(\boldsymbol{C})$ or transiently

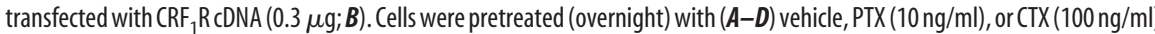
with CRF (100 nM), orexin-A (50 nM), or both (E). A-C, Representative picometer shifts of reflected light wavelength (picometers) versus time; each curve shows the mean of a representative optical trace experiment performed in triplicate. $\boldsymbol{D}, \boldsymbol{E}$, Maximum responses are derived from the resulting picometer shifts of reflected light wavelength (picometers) versus time curves. Values are means \pm SEMs of four to five experiments per group. One-way ANOVA followed by Bonferroni's multiple comparison post hoc tests show significant agonist effect versus basal values $\left.{ }^{* * *} p<0.001\right)$, no significant effect of CRF plus orexin-A treatment versus CRF or orexin-A treatment, and significant effect of agonist plus antagonist or toxin treatment versus agonist alone ( ${ }^{\& \&} p<0.001$ ).

SB334867 (Fig. 2H). A canonical $\mathrm{G}_{\mathrm{s}}-\mathrm{G}_{\mathrm{i}}$ interaction at the adenylyl-cyclase level could not be observed during coactivation of both receptors with CRF and orexin-A, showing cAMP accumulation similar to that obtained with CRF alone (Fig. $2 H$ ). This would indicate a negative crosstalk by which $\mathrm{CRF}_{1} \mathrm{R}$ activation counteracts $\mathrm{OX}_{1} \mathrm{R}$ signaling through $\mathrm{G}_{\mathrm{i}}$ in the $\mathrm{CRF}_{1} \mathrm{R}-\mathrm{OX} \mathrm{X}_{1} \mathrm{R}$ heteromer. These findings were supported with experiments using label-free DMR technology, which allows measuring G-proteinmediated signaling in living cells. Agonist-induced timeresponse curves in the absence or presence of pertussis toxin (PTX) or cholera toxin (CTX) were obtained in cells expressing both $\mathrm{OX}_{1} \mathrm{R}$ and $\mathrm{CRF}_{1} \mathrm{R}$ (Fig. 3A). The maximum response in- 
A

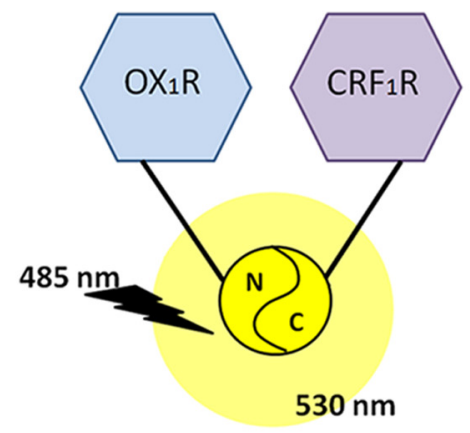

C

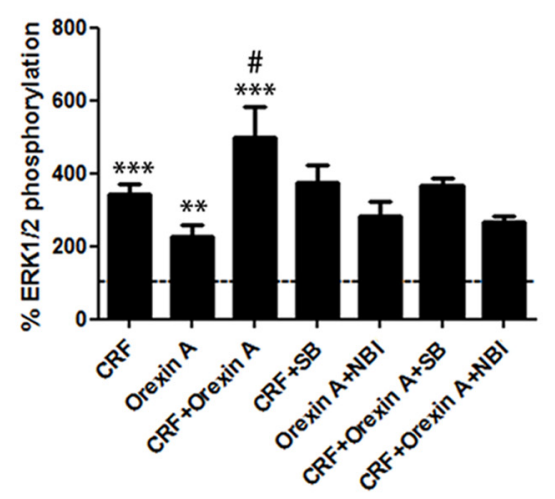

B

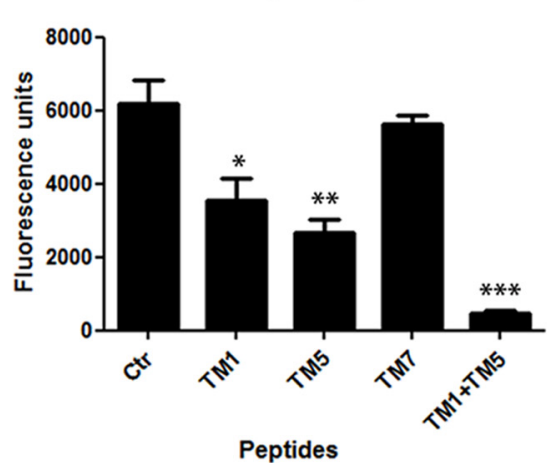

D $\quad \mathrm{CRF}_{1} \mathrm{R} / \mathrm{OX}{ }_{1} \mathrm{R}+\mathrm{TM} 5$

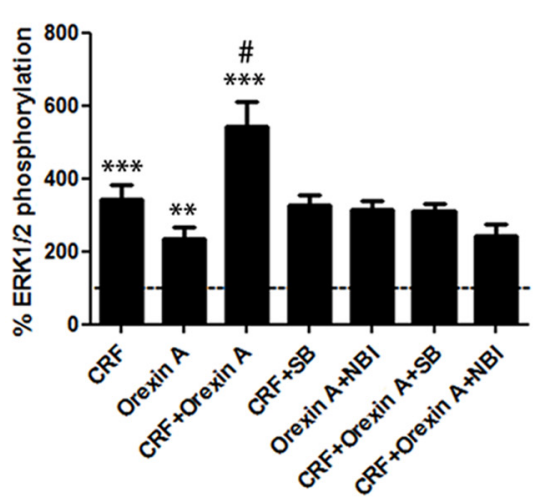

E

E $\quad \mathrm{CRF}_{1} \mathrm{R} / \mathrm{OX} \mathrm{X}_{1} \mathrm{R}+\mathrm{TM} 7$

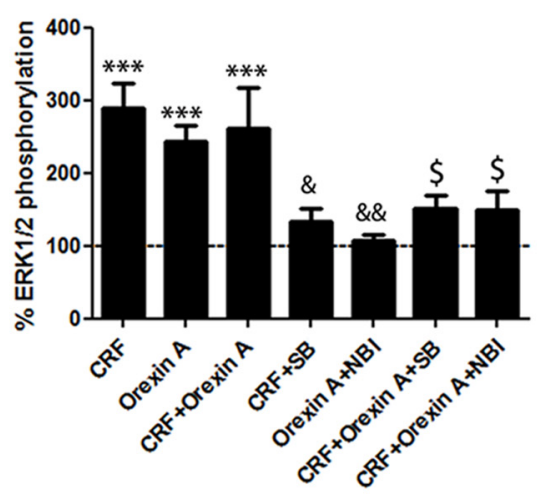

Figure 4. Effect of interfering synthetic peptides on the structure and function of $C R F_{1} R-O X_{1} R$ heteromers. $A$, Scheme showing BiFC. $B$, Disruptive effect of HIV TAT-fused peptides with the amino acid sequences of $0 X_{1} R$ TM1, TM5, and TM7 on fluorescence emitted by HEK-293T cells cotransfected with $\mathrm{CRF}_{1} \mathrm{R}-\mathrm{nVenus} \mathrm{CDNA}(0.6 \mu \mathrm{M})$ and $0 \mathrm{X}_{1} \mathrm{R}-\mathrm{cVenus}$ CDNA $(0.6$ $\mu \mathrm{M}$ ). Values (fluorescence at $530 \mathrm{~nm}$ ) are means \pm SEMs of six to seven experiments per group. One-way ANOVA followed by Bonferroni's multiple comparison post hoc test shows significant differences versus control $\left(\mathrm{Ctr} ;{ }^{*} p<0.05\right.$, ${ }^{* *} p<$ 0.01 , and $\left.{ }^{* * *} p<0.001\right)$. C $-E$, Disruptive effect of HIV TAT-fused peptides on ERK1/2 phosphorylation in HEK-293T cells transfected with $C_{1} R_{1} R$ CDNA $(0.3 \mu \mathrm{g})$ and $0 \mathrm{X}_{1} \mathrm{R}$ CDNA $(0.4 \mu \mathrm{g})$ preincubated (60 min) with $0 \mathrm{X}_{1} \mathrm{R}$ TM1, TM5, or TM7 (4 $\mu \mathrm{M}$ ), pretreated (20 min) with vehicle, the $0 \mathrm{X}_{1} \mathrm{R}$ antagonist SB334667 (SB; $\left.1 \mu \mathrm{M}\right)$, or the $\mathrm{CRF}_{1} \mathrm{R}$ antagonist NBI27914 (NBI; $1 \mu \mathrm{M})$, followed by treatment ( $7 \mathrm{~min})$ with medium, (RF $(100 \mathrm{~nm})$, orexin-A $(50 \mathrm{nM})$, or both. Values are means \pm SEMs of five to six experiments expressed as percentage of basal (100\%; dotted line). One-way ANOVA followed by Bonferroni's multiple comparison post hoc test shows significant differences of agonist treatment versus basal values ${ }^{* *} p<0.01$ and $\left.{ }^{* * *} p<0.001\right)$, CRF plus orexin-A treatment versus (RF or orexin-A treatment $\left({ }^{\#} p<0.05\right)$, one agonist plus antagonist versus agonist alone $\left({ }^{\&} p<0.05\right.$ and $\left.{ }^{\& \&} p<0.01\right)$, or both agonists plus NBI27914 versus CRF, or both agonists plus SB 334867 versus orexin- $A\left({ }^{\$} p<0.05\right)$.

duced by orexin-A or CRF (derived from time-response curves) was significantly inhibited with pretreatment with either PTX or CTX (Fig. 3D). Conversely, in cells only expressing $\mathrm{CRF}_{1} \mathrm{R}$, the effect of $\mathrm{CRF}$ was inhibited by CTX but not with PTX (Fig. 3B), whereas in cells only expressing $\mathrm{OX}_{1} \mathrm{R}$, the effect of orexin-A was only inhibited by PTX (Fig. 3C). These results demonstrate that the heteromer can interact simultaneously with both $\mathrm{G}_{\mathrm{i}}$ - and $\mathrm{G}_{\mathrm{s}}$-proteins. Negative crosstalk and cross-antagonism were also observed by DMR. The effect (maximum response) of CRF or orexin-A was inhibited by both NBI27914 and SB334867, and the coactivation with CRF and orexin-A produced a lower response than the one obtained by single activation (Fig. 3E). These results suggest strongly that negative crosstalk and cross-antagonism observed for G-protein-dependent and $\beta$-arrestin-dependent signaling pathways constitute biochemical characteristics of $\mathrm{CRF}_{1} \mathrm{R}-\mathrm{OX}_{1} \mathrm{R}$ heteromers.

BiFC experiments (Fig. 4A) were performed to check the ability of peptides with the amino acid sequence of $\mathrm{OX}_{1} \mathrm{R} T \mathrm{TM}$ domains to destabilize $\mathrm{CRF}_{1} \mathrm{R}-\mathrm{OX}_{1} \mathrm{R}$ heteromer, as described recently for the dopamine $\mathrm{D}_{1}-\mathrm{D}_{3}$ receptor heteromer (Guitart et al., 2014). HIV TAT peptides fused to $\mathrm{OX}_{1} \mathrm{R}$ TM1, TM5, and TM7 peptides were used. Significant fluorescence could be detected in HEK-293T cells transfected with $\mathrm{CRF}_{1} \mathrm{R}$ fused to the $\mathrm{N}$-terminal fragment of YFP Venus (nVenus) and $\mathrm{OX}_{1} \mathrm{R}$ fused to the C-terminal fragment YFP Venus (cVenus) as a result of YFP Venus reconstitution by $\mathrm{CRF}_{1} \mathrm{R}-\mathrm{OX}_{1} \mathrm{R}$ heteromerization. Treatment with $\mathrm{OX}_{1} \mathrm{R}$ TM1 and TM5 peptides alone or in combination, but not TM7, inhibited YFP Venus reconstitution, and the effect of TM1 plus TM5 was more pronounced than the effect obtained by either peptide alone (Fig. $4 B)$. ERK1/2 phosphorylation crosstalk and cross-antagonism experiments were then performed in cells pretreated with $\mathrm{OX}_{1} \mathrm{R}$ TM1 (Fig. 4C) or TM5 (Fig. 4D) peptides. Both peptides counteracted the negative crosstalk and cross-antagonism (Fig. 4C,D). Importantly, TM7 peptide, which was not able to alter the structure of $\mathrm{CRF}_{1} \mathrm{R}-\mathrm{OX}_{1} \mathrm{R}$ in BiFC experiments, was also ineffective at counteracting the negative crosstalk and cross-antagonism (Fig. 4E). None of the peptides themselves significantly changed signaling from each of the receptors when activated alone with their respective agonists (Fig. 4C$E$ ). These results demonstrate that the negative crosstalk and cross-antagonism depend on the integrity of the quaternary structure of the $\mathrm{CRF}_{1} \mathrm{R}-\mathrm{OX}_{1} \mathrm{R}$ heteromer and, therefore, that constitute biochemical characteristics of the heteromer. 
Two $\mathrm{CRF}_{1} \mathrm{R}$ functional mutants were used to provide some insight about the conformational changes involved in the negative crosstalk between ligands binding to the $\mathrm{CRF}_{1} \mathrm{R}-\mathrm{OX}_{1} \mathrm{R}$ heteromer: (1) a truncated mutant $\left(\mathrm{CRF}_{1} \mathrm{R} 433\right)$ that lacks a large part of the $\mathrm{N}$-terminal domain and is not able to bind CRF but can still be activated by a small peptide that corresponds to the $\mathrm{N}$-terminal part of CRF (peptide $14 \mathrm{~b}$, which binds to the juxtamembrane activating domain of $\mathrm{CRF}_{1} \mathrm{R}$; Devigny et al., 2011); and (2) a receptor that contains a mutation in the third intracellular loop and has enhanced constitutive activity $\left(\mathrm{CRF}_{1} \mathrm{R}_{432}\right)$. Both mutants were able to form heteromers with $\mathrm{OX}_{1} \mathrm{R}$ as detected by BRET experiments without significant differences in $\mathrm{BRET}_{\max }$ and $\mathrm{BRET}_{50}$ with respect to the $\mathrm{CRF}_{1} \mathrm{R}$ (Fig. $5 A, B$ ). As expected, CRF or orexin-A did not induce ERK1/2 phosphorylation in HEK-293T cells expressing $\mathrm{CRF}_{1} \mathrm{R} 433$ alone (Fig. $5 C)$. Orexin-A, but not CRF, was able to signal in cells expressing $\mathrm{CRF}_{1} \mathrm{R} 433-$ $\mathrm{OX}_{1} \mathrm{R}$ heteromers, but orexin-A-induced signaling was not modified by CRF or the $\mathrm{CRF}_{1} \mathrm{R}$ antagonist NBI27914 (Fig. 5D,E). Nevertheless, in these cells, peptide $14 \mathrm{~b}$ promoted ERK1/2 phosphorylation, and a negative crosstalk was observed between orexin-A and peptide $14 \mathrm{~b}$ (Fig. $5 F$ ). These results indicate that an active conformation of the $\mathrm{CRF}_{1} \mathrm{R}$ is involved with the negative crosstalk of receptor agonists in the $\mathrm{CRF}_{1} \mathrm{R}-\mathrm{OX}_{1} \mathrm{R}$ heteromer. This was further corroborated using the $\mathrm{CRF}_{1} \mathrm{R} 432$ mutant, which displays high constitutive activity. Single expression of $\mathrm{CRF}_{1} \mathrm{R} 432$ showed increased basal ERK1/2 phosphorylation (compared with nontransfected cells), which could not be increased further by CRF (Fig. 5G). The same findings were also obtained in cells expressing $\mathrm{CRF}_{1} \mathrm{R} 432$ and $\mathrm{OX}_{1} \mathrm{R}$ (Fig. $5 H$ ). In addition, orexin-A did not increase MAPK signaling, in agreement with the active conformation of $\mathrm{CRF}_{1} \mathrm{R}$ facilitating an allosteric inhibition of the orexin-A signaling (Fig. 5H).

\section{$\mathrm{CRF}_{1} \mathrm{R}-\mathrm{OX}_{1} \mathrm{R}$ heteromers in the VTA} control dendritic dopamine release In rat VTA slices, orexin-A and CRF promoted ERK1/2 phosphorylation (Fig. $6 A)$, coactivation with orexin-A and CRF showed negative crosstalk, and both the $\mathrm{CRF}_{1} \mathrm{R}$ antagonist NBI27914 and the $\mathrm{OX}_{1} \mathrm{R}$ antagonist SB334867, which do not modify basal levels by themselves, antagonized the effect of orexin-A and CRF, thus showing cross-antagonism (Fig. 6A). Crosstalk and cross-antagonism disap-
A

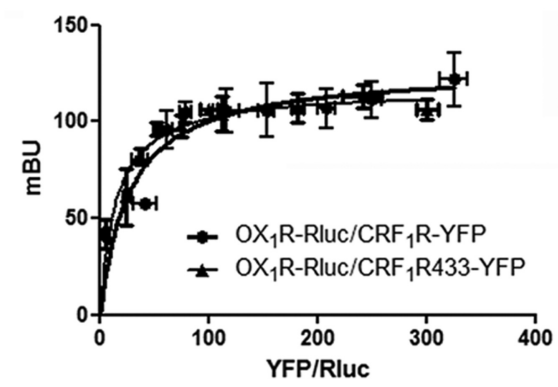

C

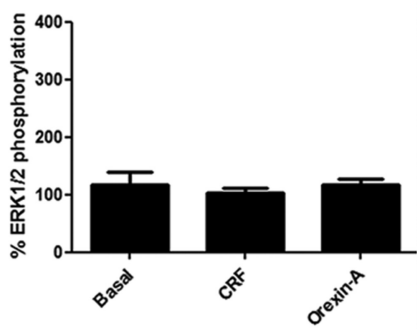

E

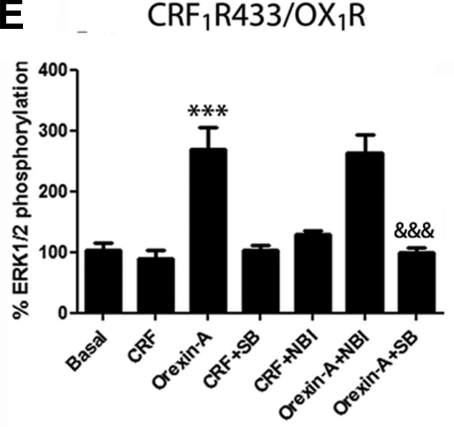

G

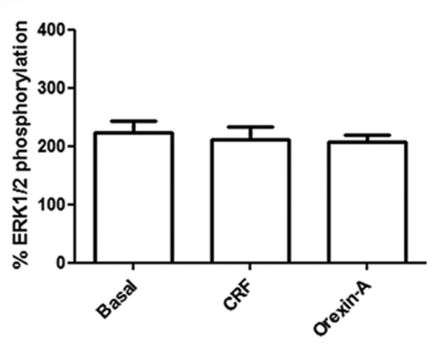

B

D

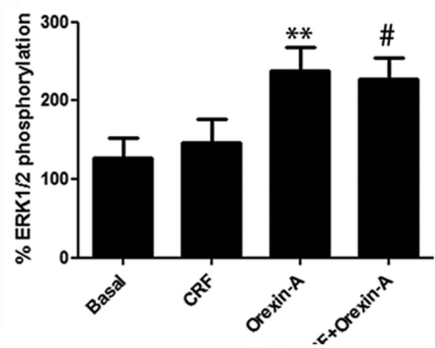

$\mathbf{F}$

$\mathrm{CRF}_{1} \mathrm{R} 333 / \mathrm{OX}_{1} \mathrm{R}$

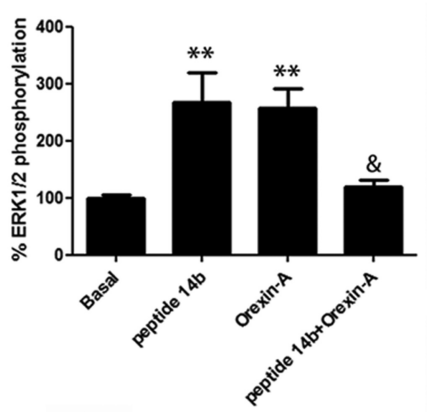

H

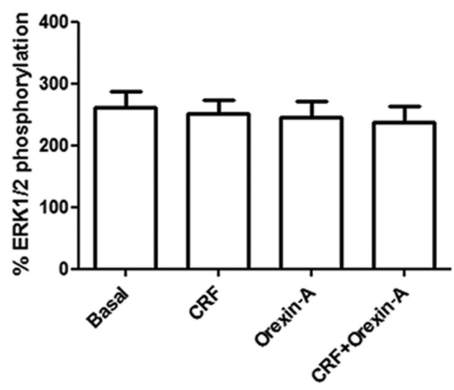

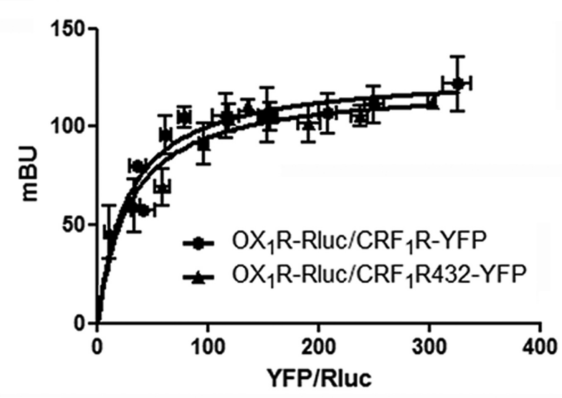

Figure 5. Involvement of the active conformation of $\mathrm{CRF}_{1} R$ with the negative crosstalk of receptor agonists in the $\mathrm{CRF}_{1} \mathrm{R}-\mathrm{OX} \mathrm{X}_{1} \mathrm{R}$ heteromer. $A, B, B R E T$ saturation experiments in HEK-293T cells transfected with OX ${ }_{1} R-R L u c$ CDNA $(0.2 \mu \mathrm{g})$ and increasing CDNA amounts ( $0.05-0.5 \mu \mathrm{g}$ ) of CRF $_{1} \mathrm{R}-\mathrm{YFP}$ (circles), CRF1R433 mutant (triangles in $\boldsymbol{A}$ ), or CRF $_{1}$ R432 mutant (triangles in $\boldsymbol{B}$ ). BRET is expressed as $\mathrm{mBU}$ as a function of $1000 \times$ the ratio between fluorescence of the acceptor (YFP) and Luciferase activity of the donor (RLuc). Values are means \pm SEMs of five to six replications of one independent experiment per point. C $-F$, ERK1/2 phosphorylation in HEK-293T cells transfected with CRF1R433 mutant CDNA $\left(0.3 \mu \mathrm{g} ;(\boldsymbol{B})\right.$ alone or transfected with $0 \mathrm{X}_{1} \mathrm{R}$ cDNA $(0.4 \mu \mathrm{g})$ pretreated (10 min) with vehicle, the $0 X_{1} R$ antagonist SB334667 (SB; $1 \mu \mathrm{M}$ ), or the $\mathrm{CRF}_{1} R$ antagonist NBI27914 (NBI; $1 \mu \mathrm{M}$ ), followed by treatment ( $7 \mathrm{~min})$ with CRF (100 nM), orexin-A $(50 \mathrm{~nm})$, or both, or with peptide $14 \mathrm{~b}(10 \mathrm{~nm} ;(-E)$. Values are means \pm SEMs of five to six experiments per group expressed as percentage of basal (100\%). One-way ANOVA followed by Bonferroni's multiple comparison post hoc test shows significant differences of single agonist treatment versus basal values ( ${ }^{* *} p<0.01$ and ${ }^{* * *} p<0.001$ ), CRF plus orexin-A treatment versus CRF or orexin-A treatment ( ${ }^{\#} p<0.05$ ) or orexin-A plus SB334667 or peptide $14 \mathrm{~b}$ versus orexin-A alone ( ${ }^{\&} p<0.05$ and $\left.{ }^{\& \& \&} p<0.001\right) . \mathbf{G}, \boldsymbol{H}$, ERK1/2 phosphorylation in HEK-293T cells transfected with CRF1R432 mutant CDNA $(0.3 \mu \mathrm{g} ; \boldsymbol{F})$ alone or transfected with $0 \mathrm{X}_{1} \mathrm{R}(0.4 \mu \mathrm{g})$ treated $(7 \mathrm{~min})$ with vehicle or with CRF (100 nM), orexin-A (50 $\mathrm{nM}$ ) or both $(G)$. Values are means \pm SEMs of five to six experiments per group expressed as percentage of basal values obtained in nontransfected cells (100\%). 
A

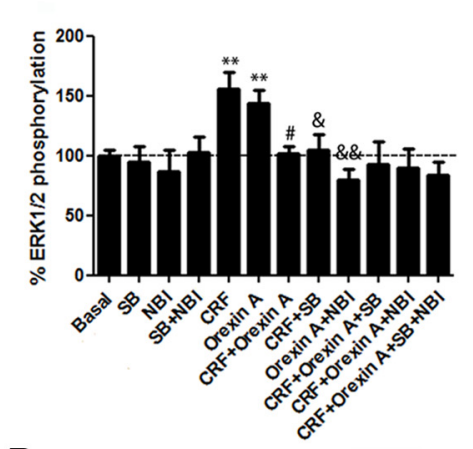

D

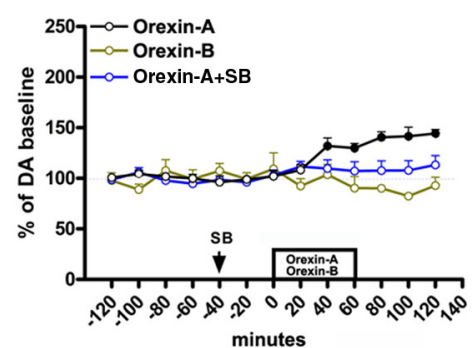

B

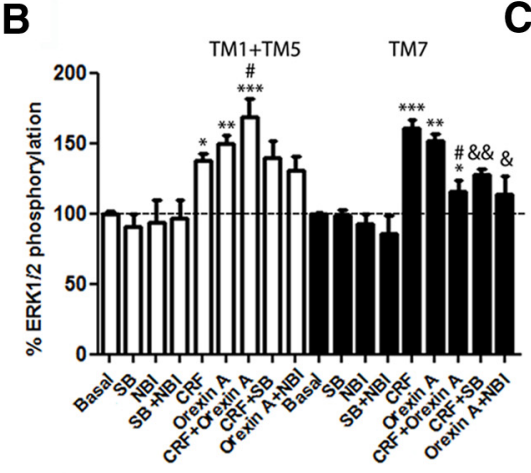

E

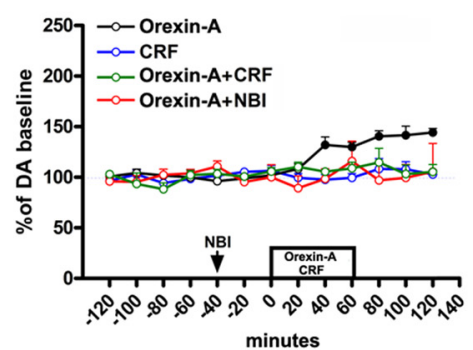

C

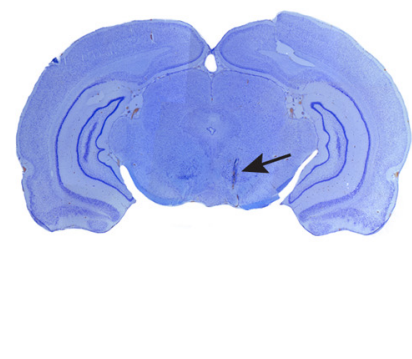

$\mathbf{F}$

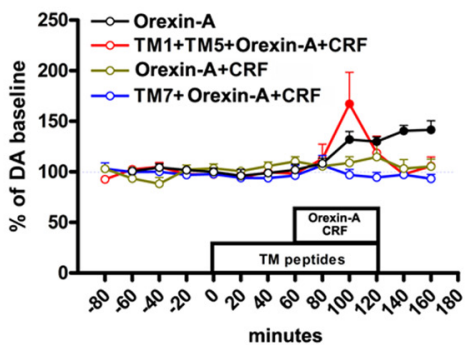

Figure 6. Expression and function of CRF $R-0 X_{1} R$ heteromers in the VTA. $A, B, E R K 1 / 2$ phosphorylation in rat VTA slices preincubated $(3 \mathrm{~h})$ with vehicle $(\boldsymbol{A})$ or HIV TAT-fused peptides with the

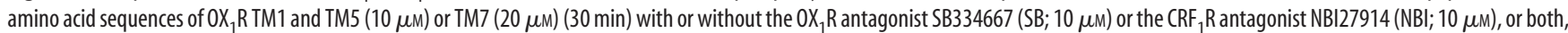
followed by incubation (10 min) with vehicle, $(R F(1 \mu \mathrm{M})$, orexin- $A(1 \mu \mathrm{M})$, or both $(B)$. Values are means \pm SEMs of five to six experiments per group expressed as percentage of basal values (100\%). One-way ANOVA followed by Bonferroni's multiple comparison post hoc test shows significant differences of agonist treatment versus basal values $\left({ }^{*} p<0.05\right.$, ${ }^{* *} p<0.01$, and $\left.{ }^{* * *} p<0.001\right)$, CRF plus orexin-A treatment versus (RF or orexin-A treatment $\left({ }^{\#} p<0.05\right)$, or agonist plus antagonist treatment versus agonist alone $\left({ }^{\&} p<0.05\right.$ and $\left.{ }^{\text {\&\& }} p<0.01\right)$. C, Representative coronal section of a rat brain $(5.6 \mathrm{~mm}$ posterior from bregma), stained with cresyl violet, showing the track left by the tip of the modified microdialysis probe in the VTA (arrow). D, E, Dopamine (DA) levels in dialysates sampled from the VTA after slow infusion $(1 \mu \mathrm{l} / \mathrm{h})$ of orexin- $\mathrm{A}(1 \mu \mathrm{l}, 10 \mu \mathrm{M})$, orexin $\mathrm{B}(1 \mu \mathrm{l}, 10 \mu \mathrm{M})$, and/or CRF $(1 \mu \mathrm{l}, 10 \mu \mathrm{M})$ after previous systemic (intraperitoneal) administration of vehicle, SB334667 (SB; $10 \mathrm{mg} / \mathrm{kg} ; \boldsymbol{D})$ ) or NBI27914 (NBI; $10 \mathrm{mg} / \mathrm{kg} ; \boldsymbol{E}$ ) or with preinfusion and coinfusion $\left(1 \mu \mathrm{l} / \mathrm{h}\right.$ ) of $0 \mathrm{X}_{1} \mathrm{R}$ TM1 plus TM5 (30 $\left.\mu \mathrm{M}\right)$ or TM7 (60 $\left.\mu \mathrm{M}\right)(\boldsymbol{F})$. Values are means \pm SEMs of 7-10 experiments per group and are expressed as percentage of basal values (average of first 3 values before orexin- $A$ or (RF infusion). A repeated measures ANOVA followed by Bonferroni's multiple comparison post hoc test showed significant difference (filled symbols, $p<0.05$ ) versus the last basal values before orexin-A or CRF infusion. The same data on the effect of infusion of orexin-A alone are shown in $\mathbf{D}-\boldsymbol{F}$ for comparison.

peared when VTA slices were treated with the $\mathrm{CRF}_{1} \mathrm{R}-\mathrm{OX}_{1} \mathrm{R}$ destabilizing peptides $\mathrm{OX}_{1} \mathrm{R}$ TM1 plus TM5 (10 $\mu \mathrm{M}$; Fig. $6 B$ ), whereas the negative control TM7 peptide (at the same total peptide concentration, $20 \mu \mathrm{M}$ ) was ineffective (Fig. $6 B$ ), which demonstrates the presence of $\mathrm{CRF}_{1} \mathrm{R}-\mathrm{OX}_{1} \mathrm{R}$ heteromers in the VTA.

To investigate the functional role of $\mathrm{CRF}_{1} \mathrm{R}-\mathrm{OX} \mathrm{X}_{1} \mathrm{R}$ heteromers in the VTA, we analyzed dopamine release in the VTA using in vivo microdialysis experiments (Fig. $6 C-F$ ). Dendritic dopamine release by mesencephalic dopaminergic cells resembles that of the terminal regions, possessing a similar uptake mechanism and a finite releasable storage pool (Kita et al., 2009). Furthermore, local dopamine release in the VTA is a correlate of dopaminergic cell firing (Legault and Wise, 1999). Initial attempts to perfuse orexin-A through the dialysis probe (reverse dialysis) were unsuccessful, which included testing of different compositions of ACSF and different dialysis membranes of different materials and different cutoff, as analyzed with mass-spectrometry analysis of in vitro-recovered dialysates (data not shown). A specialized probe with an embedded silica infusion port was designed (Fig. 7) that allowed simultaneous constant slow delivery $\left(1 \mu \mathrm{l} / \mathrm{h}\right.$ ) of large peptides (ligands and $\mathrm{OX}_{1} \mathrm{R}$ TM peptides) in the same brain region where the microdialysis probe is sampling the extracellular concentration of dopamine. VTA infusion of orexin-A $(10 \mu \mathrm{M})$ for 60 min produced dopamine release, which remained elevated $>1 \mathrm{~h}$ after withdrawal (Fig. $6 D$ ). The average basal dialysate concentration of dopamine of a total of 121 animals was $2.37 \pm 0.15 \mathrm{nM}$ (mean \pm SEM). This effect was attrib- utable to selective activation of $\mathrm{OX}_{1} \mathrm{R}$, because it was not reproduced by a $10 \mu \mathrm{M}$ infusion of the selective $\mathrm{OX}_{2} \mathrm{R}$ agonist orexin-B (Sakurai et al., 1998; de Lecea et al., 1998) and was counteracted by the previous systemic administration of an effective dose (10 mg/kg, i.p.) of the selective $\mathrm{OX}_{1} \mathrm{R}$ receptor antagonist SB334867 (Richards et al., 2008; Fig. 6D). The infusion of CRF $(10 \mu \mathrm{M})$ or the systemic administration of an effective dose $\left(10 \mathrm{mg} / \mathrm{kg}\right.$, i.p.) of the $\mathrm{CRF}_{1} \mathrm{R}$ antagonist NBI27914 did not produce any significant change in the extracellular concentration of dopamine, but both counteracted the effect of orexin-A (Fig. 6E), demonstrating the negative crosstalk and cross-antagonism. These results strongly suggest that dendritic VTA dopamine release is under the control of $\mathrm{CRF}_{1} \mathrm{R}-\mathrm{OX}_{1} \mathrm{R}$ heteromers. This was further demonstrated using $\mathrm{CRF}_{1} \mathrm{R}-\mathrm{OX}_{1} \mathrm{R}$ destabilizing peptides. Infusion of $\mathrm{OX}_{1} \mathrm{R}$ TM1 $(30 \mu \mathrm{M})$ plus TM5 $(30 \mu \mathrm{M})$ peptides but not the control TM7 peptide (at the same total peptide concentration, $60 \mu \mathrm{M}$ ) counteracted the orexin-A-CRF negative crosstalk (Fig. $6 F$ ). The effect of the TM peptides was not long lasting, probably because of a faster clearance compared with that of the larger and more hydrophilic orexin-A and CRF molecules. These results demonstrate that $\mathrm{CRF}_{1} \mathrm{R}-\mathrm{OX}_{1} \mathrm{R}$ heteromers modulate VTA dopamine release.

$\mathrm{CRF}_{1} \mathrm{R}-\mathrm{OX} \mathrm{X}_{1} \mathrm{R}$ heteromers are signaling units that can be modulated by cocaine in transfected cells and the VTA In cells expressing $\mathrm{CRF}_{1} \mathrm{R}$ and $\mathrm{OX}_{1} \mathrm{R}$, pretreatment for $2 \mathrm{~h}$ with 30 $\mu \mathrm{M}$ cocaine completely disrupted the negative crosstalk and 
A

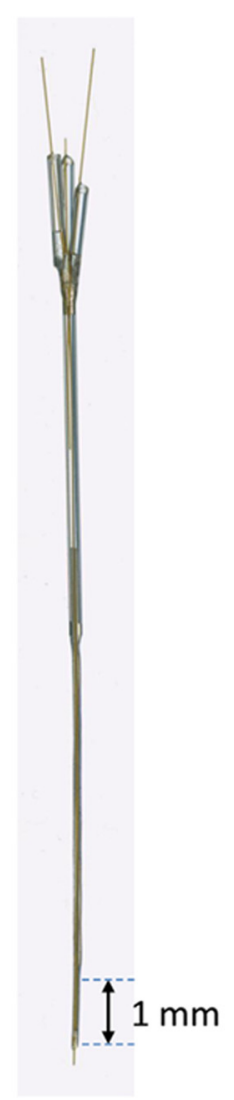

B

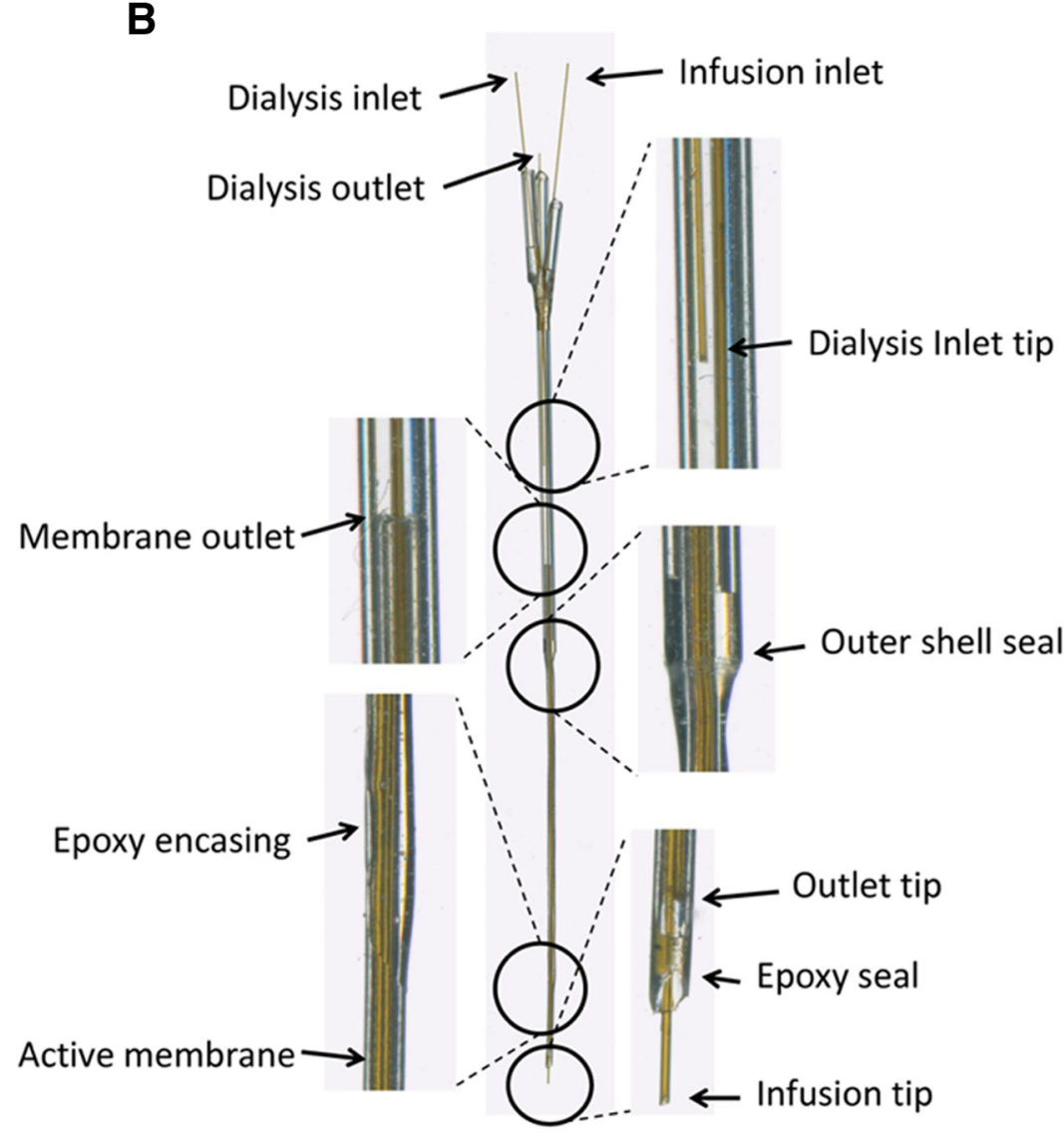

Figure 7. Microdialysis probe with infusion port. $A$, Magnification showing the length of the dialysis membrane between dotted lines (1 mm). $B$, Amplification of different parts of the probe (on a borosilicate glass model to show inner details). Internal tubing and infusion port are made of fused silica ( $40 \mathrm{~mm}$ internal diameter). The dialysis membrane (AN69) has a $20 \mathrm{kDa}$ molecular weight cutoff. Seals are made of epoxy resin. The design allows the infusing of large peptides in the same brain region being analyzed for extracellular levels of dopamine.

cross-antagonism between $\mathrm{CRF}_{1} \mathrm{R}$ and $\mathrm{OX}_{1} \mathrm{R}$ ligands on MAPK signaling (Fig. $8 A$, black, bars) and $\beta$-arrestin 2 recruitment (Fig. $8 B$, black bars) that was seen in the absence of cocaine (Fig. $8 A, B$, white bars). Thus, cocaine blocks the allosteric intermolecular interactions in the $\mathrm{CRF}_{1} \mathrm{R}-\mathrm{OX}_{1} \mathrm{R}$ heteromers that conduce the crosstalk and cross-antagonism between $\mathrm{CRF}_{1} \mathrm{R}$ and $\mathrm{OX}_{1} \mathrm{R}$ ligands.

We next explored the effect of cocaine in the rat VTA. The extracellular level of cocaine in the rat brain reached after pharmacologically significant doses is estimated to be $15 \mu \mathrm{M}$ (Pettit et al., 1990). A higher cocaine concentration $(100 \mu \mathrm{M})$ was then used to allow diffusion into the VTA slices. Cocaine pretreatment for $4 \mathrm{~h}$ counteracted the negative crosstalk of orexin-A and CRF on ERK1/2 phosphorylation. Furthermore, crossantagonism of SB334867 or NBI27914 on ERK1/2 phosphorylation induced by CRF or orexin-A was not observed (Fig. $8 C)$. Therefore, cocaine also disrupts the allosteric interactions within the $\mathrm{CRF}_{1} \mathrm{R}-\mathrm{OX}_{1} \mathrm{R}$ heteromer in the VTA.

\section{$\sigma_{1}$ Rs mediate the disruptive effects of cocaine on $\mathrm{CRF}_{1} \mathrm{R}-\mathrm{ORX} \mathrm{X}_{1} \mathrm{R}$ heteromer function}

It has been found recently that cocaine can disrupt allosteric interactions between ligands in dopamine $\mathrm{D}_{1}$ - histamine $\mathrm{H}_{3}$ receptor $\left(\mathrm{H}_{3} \mathrm{R}\right)$ heteromers by acting on $\sigma_{1}$ Rs that oligomerize with the heteromer (Moreno et al., 2014). We explored whether this mechanism could be involved in the disruptive effects of cocaine on $\mathrm{CRF}_{1} \mathrm{R}-\mathrm{ORX}_{1} \mathrm{R}$ heteromer function. A saturable BRET curve was obtained in HEK-293T cells expressing $\mathrm{CRF}_{1} \mathrm{R}-\mathrm{RLuc}$ and increasing concentrations of $\sigma_{1}$ R-YFP (Fig. $9 A$ ), indicating a direct interaction between $\sigma_{1} \mathrm{R}$ and $\mathrm{CRF}_{1} \mathrm{R}$. Cocaine produced a significant change in $\mathrm{BRET}_{\text {max }}$ and $\mathrm{BRET}_{50} \mathrm{BRET}$ values (Fig. $9 A$ ), indicating a cocaine-induced change in the quaternary structure of the $\sigma_{1} \mathrm{R}-\mathrm{CRF}_{1} \mathrm{R}$ oligomers. Conversely, no significant BRET was detected in cells expressing $\mathrm{OX}_{1} \mathrm{R}-\mathrm{RLuc}$ and $\sigma_{1} \mathrm{R}-$ YFP in the absence or presence of cocaine (Fig. $9 B$ ). These results suggest that $\sigma_{1} \mathrm{R}$ can interact with $\mathrm{CRF}_{1} \mathrm{R}-\mathrm{OX}_{1} \mathrm{R}$ heteromers by binding to $\mathrm{CRF}_{1} \mathrm{R}$ in the heteromer. The heterotrimeric complex expression was demonstrated with SRET (Fig. 10A; Carriba et al., 2008). In HEK-293T cells expressing a constant amount of $\mathrm{OX}_{1} \mathrm{R}-\mathrm{RLuc}$ and $\sigma_{1} \mathrm{R}-\mathrm{YFP}$ and increasing amounts of $\mathrm{CRF}_{1} \mathrm{R}-$ Cherry, a net SRET saturation curve was obtained (Fig. 10B) with an SRET $_{\max }$ of $0.31 \pm 0.01 \mathrm{mSU}$ and a SRET $_{50}$ of $0.08 \pm 0.01$. These results provide evidence for the existence of $\sigma_{1} \mathrm{R}-\mathrm{CRF}_{1} \mathrm{R}-$ $\mathrm{OX}_{1} \mathrm{R}$ oligomers. Cocaine produced a significant change in SRET $_{\text {max }}$ and SRET $_{50}$ values $\left(\right.$ SRET $_{\text {max }}$ of $0.19 \pm 0.03 \mathrm{mSU}$ and a SRET $_{50}$ of $0.056 \pm 0.002$ ), indicating a cocaine-induced change in the quaternary structure of the $\sigma_{1} \mathrm{R}-\mathrm{CRF}_{1} \mathrm{R}-\mathrm{OX}_{1} \mathrm{R}$ oligomers. The involvement of $\sigma_{1} \mathrm{R}$ in the effects of cocaine on $\mathrm{CRF}_{1} \mathrm{R}-$ $\mathrm{OX}_{1} \mathrm{R}$ heteromers function in the VTA was demonstrated by using selective $\sigma_{1} \mathrm{R}$ ligands. In VTA slices, pretreatment for $4 \mathrm{~h}$ with the $\sigma_{1} \mathrm{R}$ agonist PRE-084 (Garcés-Ramírez et al., 2011) counteracted the negative crosstalk on ERK1/2 phosphorylation detected during CRF and orexin-A coadministration (Fig. 10C). Moreover, pretreatment with the $\sigma_{1} \mathrm{R}$ antagonist PD144418 (Akunne et al., 1997) blocked the effect of cocaine, and the negative cross- 
A

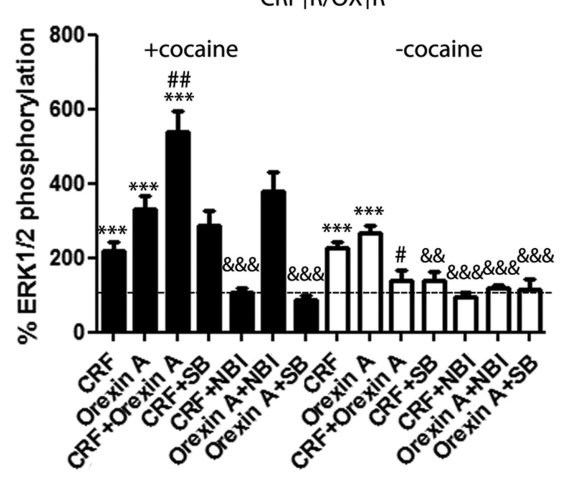

B

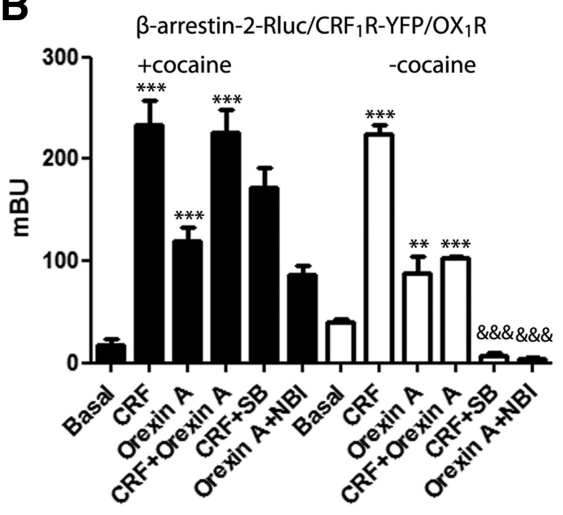

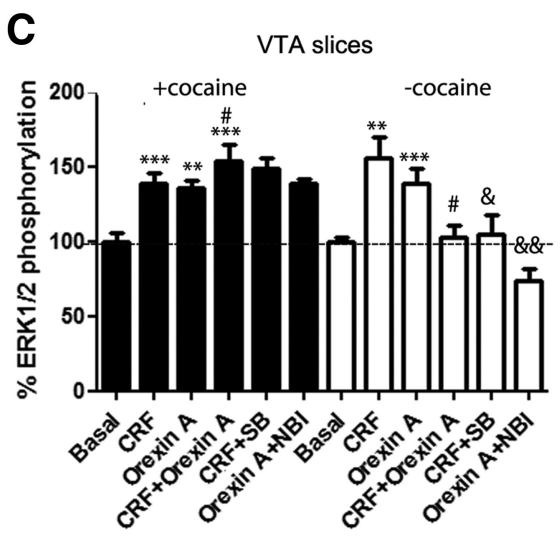

Figure 8. Cocaine-mediated disruption of negative crosstalk and cross-antagonism between $C_{2} F_{1} R$ and $O X_{1} R$ ligands in $C R F_{1} R-$ $0 \mathrm{X}_{1} \mathrm{R}$ heteromers in transfected cells and in the VTA. $A$, ERK1/2 phosphorylation in HEK-293T cells transfected with CRF $_{1} R-Y F P$ CDNA $(0.3 \mu \mathrm{g})$ and $0 \mathrm{X}_{1} \mathrm{R}-\mathrm{RLuc}$ CDNA $(0.4 \mu \mathrm{g})$ pretreated with (black bars) or without (white bars) cocaine $(30 \mu \mathrm{m}, 4 \mathrm{~h})$ and $(30$ min) with vehicle, the $\mathrm{OX}_{1} \mathrm{R}$ antagonist SB334667 (SB; $1 \mu \mathrm{M}$ ), or the $\mathrm{CRF}_{1} \mathrm{R}$ antagonist NBI27914 (NBI; $1 \mu \mathrm{m}$ ), followed by treatment ( $10 \mathrm{~min})$ with CRF $(100 \mathrm{~nm})$ or orexin- $A(50 \mathrm{~nm})$, or both. Values are means \pm SEMs of six to seven experiments per group expressed as percentage of basal values (100\%). One-way ANOVA followed by Bonferroni's multiple comparison post hoc test shows significant differences of agonist treatment versus basal values $\left({ }^{* *} p<0.01,{ }^{* * *} p<0.001\right)$, CRF plus orexin-A treatment versus (RF or orexin-A treatment ( $\left.{ }^{\# \#} p<0.01\right)$, or agonist plus antagonist treatment versus agonist alone ( $\left.{ }^{\& \& \&} p<0.001\right) . B$, $\beta$-Arrestin 2 recruitment measured by BRET in HEK-293T cells transfected with CRF $\mathrm{R}_{1} \mathrm{YFP}$ CDNA $(0.3 \mu \mathrm{g})$ and $0 \mathrm{X}_{1} \mathrm{R}$ CDNA $(0.3 \mu \mathrm{g})$ and $\beta$-arrestin 2-RLuc cDNA $(0.5 \mu \mathrm{g})$. Cells were pretreated ( $2 \mathrm{~h}$ ) with cocaine (30 $\mu \mathrm{m}$, black bars) or with medium (white bars) and (10 min) with vehicle, SB334667 (SB; $1 \mu \mathrm{M}$ ), or NBI27914 (NBI; $1 \mu \mathrm{M}$ ), followed by treatment (7 min) with CRF (100 nM), orexin-A $(50 \mathrm{~nm})$, or both. Values are means \pm SEMs of five to six experiments per group. One-way ANOVA followed by Bonferroni's multiple comparison post hoc test shows significant differences of agonist treatment versus basal $\left({ }^{* *} p<0.01\right.$ and $\left.{ }^{* * *} p<0.001\right)$ or agonist plus antagonist treatment versus agonist alone ( $\left.{ }^{\& \&} p<0.001\right)$. C, ERK1/2 phosphorylation in rat VTA slices preincubated ( $4 \mathrm{~h}$ ) with cocaine (100 $\mu \mathrm{m}$, black bars) or with vehicle (white bars) and (30 min) with vehicle, SB334667 (SB; $10 \mu \mathrm{m}$ ), or $\mathrm{NBI} 27914(\mathrm{NBl} ; 10 \mu \mathrm{M})$, followed by treatment $(10 \mathrm{~min})$ with CRF $(1 \mu \mathrm{M})$, orexin-A $(1 \mu \mathrm{M})$ or both. Values are means \pm SEMs of five to six experiments per group expressed as percentage of basal values (100\%). One-way ANOVA followed by Bonferroni's multiple comparison post hoc test shows significant differences of agonist treatment versus basal values ${ }^{* *} p<0.01$ and $^{* * *} p<$ $0.001)$, CRF plus orexin-A treatment versus (RF or orexin- $A$ treatment $\left({ }^{\#} p<0.05\right)$ or agonist plus antagonist treatment versus agonist alone ( ${ }^{\&} p<0.05$ and $\left.{ }^{\& \&} p<0.01\right)$.

talk between CRF and orexin-A was still present with preincubation of cocaine and PD144418 (Fig. 10D).

Cocaine exerts its stimulant effects predominantly by its ability to block the dopamine transporter (DAT; Kita et al., 2009). To dissect the $\sigma_{1}$ R effects in microdialysis experiments, we used the selective $\sigma_{1} \mathrm{R}$ agonist PRE-084, which reproduced the effects of cocaine in the in vitro experiments and has very low affinity for DAT (Garcés-Ramírez et al., 2011). Direct perfusion of the $\sigma_{1} \mathrm{R}$ agonist PRE-084 $(100 \mu \mathrm{M})$ through the microdialysis probe did not modify the extracellular concentration of dopamine (Fig. $10 F$ ) but counteracted the negative crosstalk between orexin-A and CRF. Thus, in the presence of PRE-084, orexin-A plus CRF produced an increase in extracellular dopamine that was larger than the one induced by orexin-A alone (Fig. 10E). In fact, in the presence of PRE-084, orexin-A was more effective, particularly during the first two samples (40 $\mathrm{min}$ ) after its infusion. Interestingly, CRF, which was ineffective by itself, also produced a prolonged significant elevation of extracellular dopamine during perfusion with the $\sigma_{1} \mathrm{R}$ agonist (Fig. 10F). These results match with the in vitro experiments and indicate the existence of a negative crosstalk between orexin-A and CRF, which is counteracted by $\sigma_{1} \mathrm{R}$ activation. These striking results are in total agreement with $\sigma_{1} \mathrm{R}-\mathrm{CRF}_{1} \mathrm{R}-\mathrm{OX}_{1} \mathrm{R}$ oligomers modulating VTA dopamine release.

We then studied whether one single administration of cocaine $(15 \mathrm{mg} / \mathrm{kg})$ could also reproduce the effects of the acute perfusion of the $\sigma_{1} \mathrm{R}$ agonist PRE084 attributable to a long-term disruption of the allosteric interactions in the $\mathrm{CRF}_{1} \mathrm{R}-\mathrm{OX}_{1} \mathrm{R}$ heteromer, as demonstrated recently for $\sigma_{1} \mathrm{R}-\mathrm{D}_{1} \mathrm{R}-\mathrm{H}_{3} \mathrm{R}$ oligomers (Moreno et al., 2014). In fact, a significant elevation in the extracellular concentration of VTA dopamine was observed after infusion of CRF or coinfusion of orexin-A and CRF (Fig. 10G).

\section{Discussion}

Class B GPCR $\mathrm{CRF}_{1} \mathrm{R}$ has been shown previously to homomerize (Milan-Lobo et al., 2009) and also heteromerize with the class A GPCRs for vasopressin and its non-mammalian vertebrate homolog vasotocin in transfected cells (Mikhailova et al., 2007; Murat et al., 2012). Similarly, evidence has been reported for $\mathrm{OX}_{1} \mathrm{R}$ homomerization and heteromerization in artificial cell systems (Ellis et al., 2006; Jäntti et al., 2014). However, although colocalized in the VTA, $\mathrm{CRF}_{1} \mathrm{R}-\mathrm{OX}_{1} \mathrm{R}$ heteromerization has not been described, and, in fact, it has been argued that independent actions of CRF and orexin-A in the VTA are involved in reinstatement of cocaine seeking (Wang et al., 2009). In the present study, we demonstrate the existence of functional $\mathrm{CRF}_{1} \mathrm{R}-\mathrm{OX}_{1} \mathrm{R}$ heteromers in transfected cells and the VTA, in which they exert a significant functional control of dopaminergic cells. By means of allosteric interactions within the $\mathrm{CRF}_{1} \mathrm{R}-\mathrm{OX}_{1} \mathrm{R}$ heteromer, $\mathrm{CRF}$ and orexin-A antagonize each other's ability to signal and promote VTA dendritic dopamine release, indicating that this heteromer should play a significant role under stress conditions, during concomitant CRF and orexin-A VTA release. Additional important findings were the evidence for oligomerization of $\sigma_{1} \mathrm{R}$ with the $\mathrm{CRF}_{1} \mathrm{R}-\mathrm{OX}_{1} \mathrm{R}$ heteromer and the ability of $\sigma_{1} \mathrm{R}$ agonists, including cocaine, to modify the quaternary structure of the heteromer to block the functional allosteric interactions between orexin-A and CRF within the heteromer.

Molecular interactions between $\mathrm{CRF}_{1} \mathrm{R}$ and $\mathrm{OX}_{1} \mathrm{R}$ were demonstrated in HEK-293T cells by using different approaches, 
A $\quad \mathrm{CRF}_{1}$ R-Rluc $/ \sigma_{1}$ R-YFP

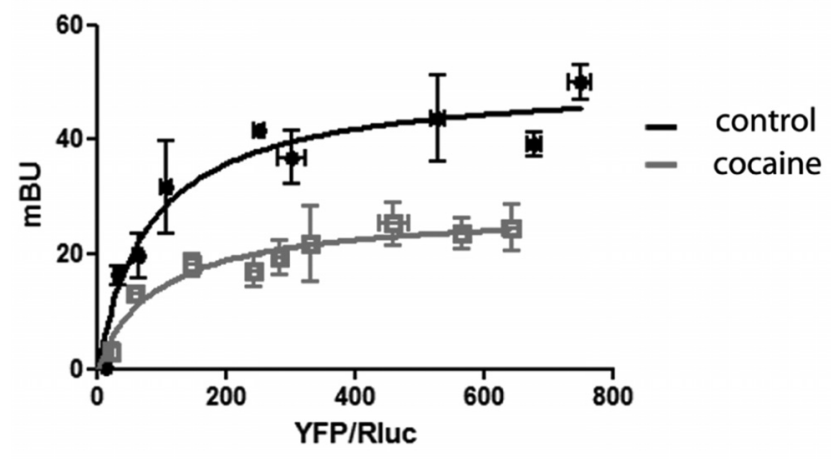

B $\quad$ OX $_{1}$ R-Rluc $/ \sigma_{1}$ R-YFP

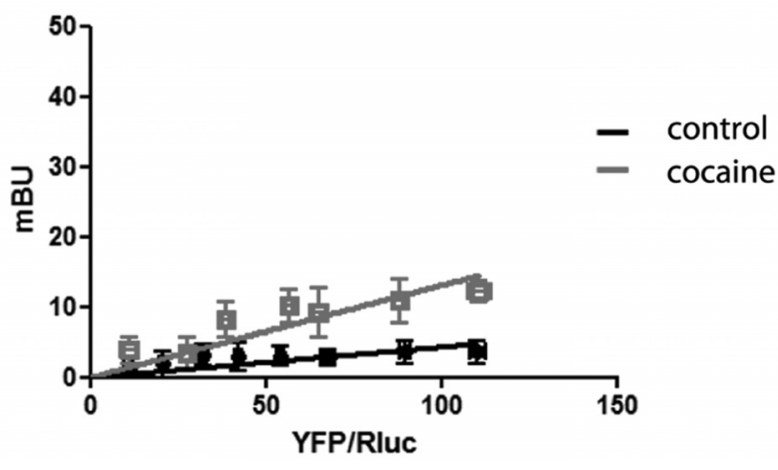

Figure 9. Interaction of $\sigma_{1} \mathrm{R}$ with $\mathrm{CRF}_{1} \mathrm{R}$. BRET saturation experiments in HEK-293T cells transfected with CRF $_{1} R-R L u c C D N A(0.3 \mu \mathrm{g} ; \boldsymbol{A})$ or $0 \mathrm{X}_{1} \mathrm{R}-\mathrm{RLuc} \mathrm{CDNA}(0.4 \mu \mathrm{g} ; \boldsymbol{B})$ with increasing amounts of $\sigma_{1} R-Y F P$ CDNA $(0.06-0.7 \mu \mathrm{g})$, in the absence (black curves) or presence (red curves) of cocaine $(30 \mu \mathrm{M})$. BRET, expressed as $\mathrm{mBU}$, is given as a function of $1000 \times$ the ratio between the fluorescence of the acceptor (YFP) and the Luciferase activity of the donor (RLuc). Values are means \pm SEMs of five to six experiments.

which included BRET, fluorescence complementation, and PLA, but also additional demonstration came from results of signaling experiments indicating the expression of $\mathrm{CRF}_{1} \mathrm{R}-\mathrm{OX}_{1} \mathrm{R}$ heteromers at the membrane level. To our knowledge, the ability of an antagonist of one receptor to block the agonist-mediated signaling of another receptor has only been reported in the frame of receptor heteromerization (Ferré et al., 2014). Also, the ability of orexin-A to induce an interaction between $\beta$-arrestin 2-RLuc and $\mathrm{CRF}_{1} \mathrm{R}-\mathrm{YFP}$ indicates recruitment of $\beta$-arrestin 2 to the $\mathrm{CRF}_{1} \mathrm{R}-\mathrm{OX}_{1} \mathrm{R}$ heteromer. Moreover, the surprising ability of PTX to counteract $\mathrm{G}_{\mathrm{s}}$-mediated $\mathrm{CRF}_{1} \mathrm{R}$ signaling and that of CTX to block $\mathrm{G}_{\mathrm{i}}$-mediated $\mathrm{OX}_{1} \mathrm{R}$ signaling indicate that the $\mathrm{CRF}_{1} \mathrm{R}$ $\mathrm{OX}_{1} \mathrm{R}$ heteromer can interact simultaneously with both $\mathrm{G}_{\mathrm{i}}$ and $\mathrm{G}_{\mathrm{s}}$ proteins showing an interdependence of $G_{i}$ and $G_{s}$ protein function in the heteromer.

Demonstration of unique biochemical properties of a receptor heteromer requires their dependence on the structural integrity of the heteromer (Ferré et al., 2009, 2014), which can be destabilized, for instance, by interfering synthetic peptides with the amino acid sequence corresponding to some TM or intracellular domains of one of the protomers (Azdad et al., 2009; He et al., 2011; Guitart et al., 2014). BRET and complementation experiments in transfected cells demonstrated that specific $\mathrm{OX}_{1} \mathrm{R}$ TM peptides and $\sigma_{1} \mathrm{R}$ agonists significantly modify the quaternary structure of the $\mathrm{CRF}_{1} \mathrm{R}-\mathrm{OX}_{1} \mathrm{R}$ heteromer. Therefore, both were used as tools to interrogate the $\mathrm{CRF}_{1} \mathrm{R}-\mathrm{OX}_{1} \mathrm{R}$ heteromer function. In fact, both $\mathrm{OX}_{1} \mathrm{R} T M$ peptides and $\sigma_{1} \mathrm{R}$ agonists sig- nificantly counteracted negative crosstalk and cross-antagonism of $\mathrm{CRF}_{1} \mathrm{R}$ and $\mathrm{OX}_{1} \mathrm{R}$ ligands, demonstrating that they constitute biochemical properties of the $\mathrm{CRF}_{1} \mathrm{R}-\mathrm{OX}_{1} \mathrm{R}$ heteromer. The application of the same tools in situ and in vivo, in VTA slices and in microdialysis experiments, further demonstrated the presence of $\mathrm{CRF}_{1} \mathrm{R}-\mathrm{OX}_{1} \mathrm{R}$ heteromers in the VTA. The very different quantitative effect of $\mathrm{OX}_{1} \mathrm{R}$ TM peptides versus $\sigma_{1} \mathrm{R}$ agonists observed in vivo, with a respective transient versus long-lasting (apparently irreversible) destabilization of $\mathrm{CRF}_{1} \mathrm{R}-\mathrm{OX}_{1} \mathrm{R}$-heteromer function, should be related to the different molecular mechanisms and different modifications of the quaternary structure of the heteromer involved. Particularly significant will be the elucidation of the apparently irreversible effect of $\sigma_{1} \mathrm{R}$ agonists, such as cocaine.

An important amount of experimental data demonstrates the involvement of $\sigma_{1} \mathrm{R}$ in many pharmacologic, including rewarding, effects of cocaine (Maurice and Su, 2009; Robson et al., 2012). Recent studies describe a role of oligomerization of $\sigma_{1} \mathrm{R}$ with $\mathrm{D}_{1} \mathrm{R}$ or $\mathrm{D}_{2} \mathrm{R}$ in the acute psychostimulants effects of cocaine (Navarro et al., 2010, 2013) and with voltage-gated Kv1.2 potassium channels in long-lasting behavioral responses (Kourrich et al., 2013). Also, oligomerization of $\sigma_{1} \mathrm{R}, \mathrm{D}_{1} \mathrm{R}$, and $\mathrm{H}_{3} \mathrm{Rs}\left(\sigma_{1} \mathrm{R}-\right.$ $\mathrm{D}_{1} \mathrm{R}-\mathrm{H}_{3} \mathrm{R}$ heteromers) has been involved in the neurotoxic effects of cocaine (Moreno et al., 2014). Interestingly, when comparing the effects of cocaine binding with either $\sigma_{1} \mathrm{R}-\mathrm{D}_{1} \mathrm{R}-$ $\mathrm{H}_{3} \mathrm{R}$ or $\sigma_{1} \mathrm{R}-\mathrm{CRF}_{1} \mathrm{R}-\mathrm{OX}_{1} \mathrm{R}$ oligomers, a common mechanism emerges, the loss of the allosteric interactions between ligands in the heteromer.

The present results strongly suggest that $\mathrm{CRF}_{1} \mathrm{R}-\mathrm{OX}_{1} \mathrm{R}$ heteromers localized in the VTA convey the previously established significant control of dopaminergic cell function by CRF and orexin- $\mathrm{A}$ in cocaine-treated animals. The counteraction of the negative crosstalk between orexin-A and CRF in the VTA by the simultaneous application of the $\sigma_{1} \mathrm{R}$ agonist PRE-084 or by the previous administration of cocaine provides a mechanism by which CRF can only induce VTA dendritic dopamine release in animals exposed previously to cocaine (Wang et al., 2005). Under these conditions, $\mathrm{CRF}_{1} \mathrm{R}$-mediated signaling is not inhibited by a tonic activation of $\mathrm{OX}_{1} \mathrm{R}$ by endogenous orexin-A. Counteraction of the allosteric interactions between agonists in the $\mathrm{CRF}_{1} \mathrm{R}-$ $\mathrm{OX}_{1} \mathrm{R}$ heteromer can also explain the apparent CRF-independent ability of orexin-A to release dopamine in the VTA and to induce cocaine seeking (Wang et al., 2009). Remarkably, in the present study, cocaine produced a modification of $\mathrm{CRF}_{1} \mathrm{R}-\mathrm{OX}_{1} \mathrm{R}$ heteromer function that was observed $24 \mathrm{~h}$ after one single systemic administration. Very similar findings were reported recently for $\sigma_{1} \mathrm{R}-\mathrm{D}_{1} \mathrm{R}-\mathrm{H}_{3} \mathrm{R}$ oligomers, in which the ability of $\mathrm{H}_{3} \mathrm{R}$ ligands to modulate $\mathrm{D}_{1} \mathrm{R}$-mediated signaling was also disrupted $24 \mathrm{~h}$ after one single systemic administration of cocaine (Moreno et al., 2014). Therefore, one single administration could explain some effects of cocaine attributed previously to its repeated administration.

Of the many new questions this study raises is the identification of the precise localization of $\mathrm{CRF}_{1} \mathrm{R}-\mathrm{OX}_{1} \mathrm{R}$ heteromers in the VTA. Both receptors are potentially colocalized in dopaminergic cells and their glutamatergic afferents Borgland et al., 2010), in which $\mathrm{CRF}_{1} \mathrm{R}-\mathrm{OX}_{1} \mathrm{R}$ heteromers could directly or indirectly control the extracellular levels of dopamine in the VTA. Second, our data indicate that, under basal conditions, the effects of CRF and orexin-A in the VTA are interdependent and mediated by $\mathrm{CRF}_{1} \mathrm{R}-\mathrm{OX}_{1} \mathrm{R}$ heteromers, but they also suggest that endogenous $\sigma_{1} \mathrm{R}$ ligands should be able to act as cocaine and therefore promote independent effects of CRF and orexin-A. Those ligands and the conditions under which they are produced in the VTA 

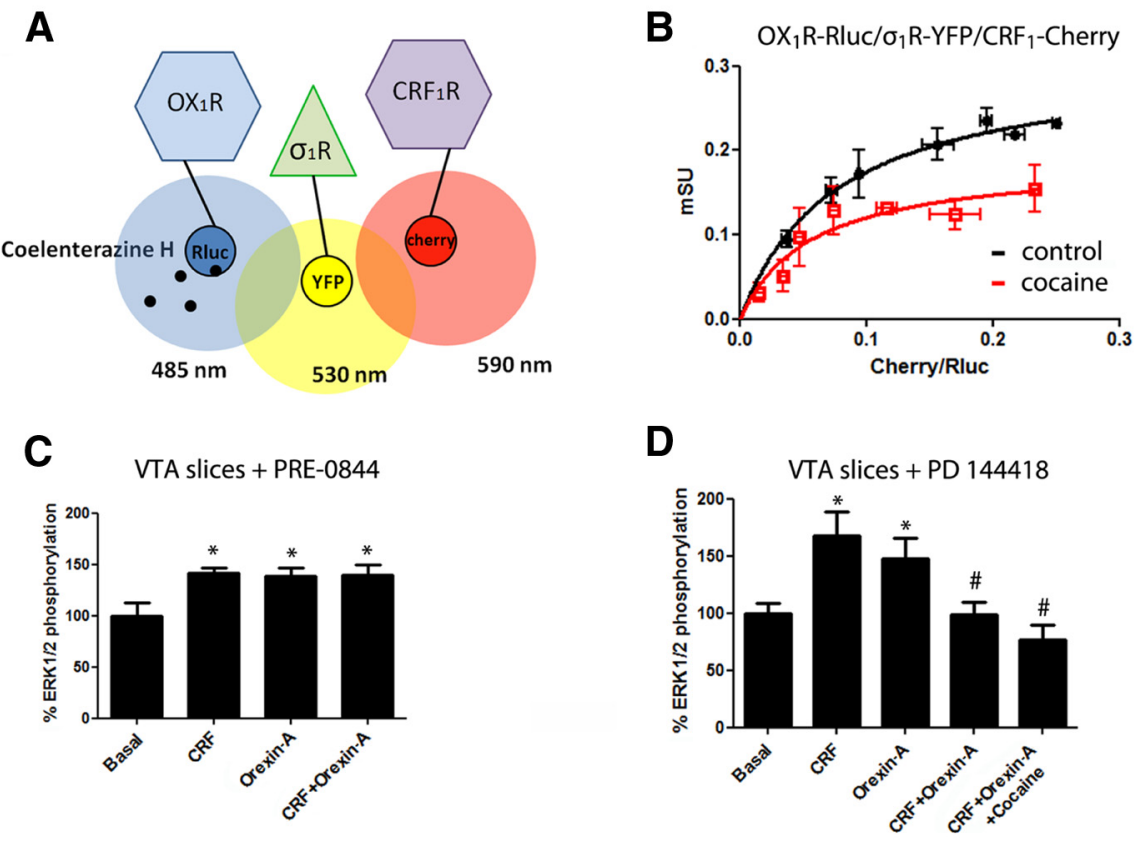

E

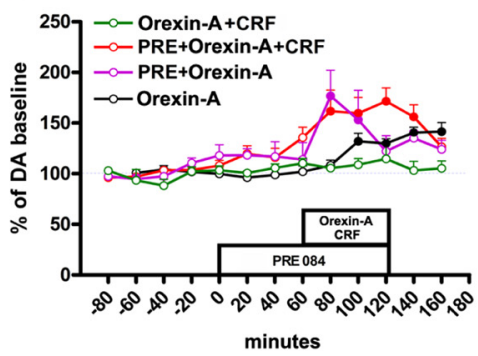

$\mathbf{F}$

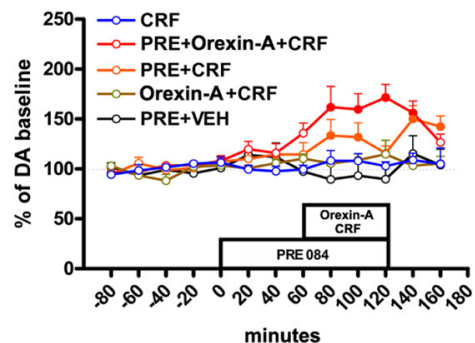

G

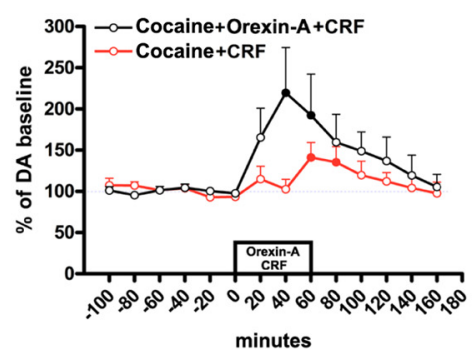

Figure 10. Involvement of $\sigma_{1} R$ in the disruptive effect of cocaine on $C R F_{1} R-O X_{1} R$ heteromer function. $A$, Scheme showing SRET (see Results). $\boldsymbol{B}$, SRET saturation experiments in HEK-293T cells expressing a constant amount of $0 X_{1} R-R L$ Luc CDNA $\left(0.2 \mu \mathrm{g}\right.$ of CDNA transfected) and $\sigma_{1} R-Y F P$ CDNA $(0.3 \mu \mathrm{g})$ and increasing amounts of CRF ${ }_{1} R-C h e r r y ~ C D N A ~(0.05-0.6$ $\mu \mathrm{g}$ ) in controls (black curve) or cocaine-treated (30 min, $30 \mu \mathrm{m}$; red curve) cells. SRET, expressed as mSU, is given as a function of the ratio between the fluorescence of the acceptor (Cherry) and the Luciferase activity of the donor (RLuC). Values are means \pm SEMs of seven to eight replications of one independent experiment per point. C, ERK1/2 phosphorylation in rat VTA slices preincubated $(4 \mathrm{~h})$ with the $\sigma_{1}$ R agonist PRE-084 (1 $\left.\mu \mathrm{M}\right)$, followed by treatment (10 min) with (RF (1 $\left.\mu \mathrm{M}\right)$, orexin-A (1 $\left.\mu \mathrm{m}\right)$, or both. D, ERK1/2 phosphorylation in rat VTA slices preincubated ( $4 \mathrm{~h}$ ) with the $\sigma_{1}$ R antagonist PD144418 $(1 \mu \mathrm{M})$, with or without cocaine $(100 \mu \mathrm{M})$, followed by treatment (10 min) with (RF $(1 \mu \mathrm{M})$, orexin-A $(1 \mu \mathrm{M})$, or both. In $C$ and $\boldsymbol{D}$, values are means \pm SEMs of five to six experiments per group expressed as percentage of basal values (100\%). One-way ANOVA followed by Bonferroni's multiple comparison post hoc test showed significant differences versus basal $\left({ }^{*} p<0.05\right)$ and (RF plus orexin-A treatment versus (RF or orexin-A treatment $\left({ }^{\#} p<0.05\right)$. $E-G$, Dopamine (DA) levels in dialysates sampled from the VTA after slow infusion $(1 \mu \mathrm{l} / \mathrm{h})$ of orexin-A $(1 \mu \mathrm{l}, 10 \mu \mathrm{M})$ and/or CRF $(1 \mu \mathrm{l}, 10 \mu \mathrm{M})$ with preinfusion and coinfusion of the $\sigma_{1}$ R agonist PRE-084 (PRE; $\left.100 \mu \mathrm{M}\right)$ or previous systemic (intraperitoneal) administration of cocaine (COC; $15 \mathrm{mg} / \mathrm{kg} ; 24 \mathrm{~h}$ before the microdialysis experiment). Values are means \pm SEMs of 7-10 experiments per group and are expressed as percentage of basal values (average of first 3 values before orexin-A or CRF infusion). A repeated-measures ANOVA (including only the basal value before orexin-A or CRF infusion) followed by Bonferroni's multiple comparison post hoc test showed significant differences (filled symbols, $p<0.05$ ) versus the last basal values before orexin-A or CRF infusion. Data on the effect of infusion of orexin-A alone in $\boldsymbol{E}$ are the same shown in Figure $6 D-F$.

still need to be determined. Third is to understand the potential changes in $\sigma_{1} \mathrm{R}-\mathrm{CRF}_{1} \mathrm{R}-\mathrm{OX}_{1} \mathrm{R}$ oligomers in acute versus longterm exposure to cocaine. It has been shown that repeated cocaine exposure increases the levels of $\sigma_{1} \mathrm{R}$ in the brain (Robson et al., 2012), and cocaine-mediated upregulation of striatal $\sigma_{1} \mathrm{R}$ has been reported to increase the presence of $\sigma_{1}-\mathrm{Kv} 1.2$ oligomers at the plasma membrane, which has been suggested to be involved in sensitization to its psychostimulants effects (Kourrich et al., 2013). Therefore, upregulation of $\sigma_{1} \mathrm{R}$ in the VTA could increase the proportion of $\sigma_{1} \mathrm{R}-\mathrm{CRF}_{1} \mathrm{R}-\mathrm{OX}_{1} \mathrm{R}$ oligomers, leading to more profound cocaine-induced changes in the control of VTA dendritic dopamine release by CRF and orexin-A. Those changes could explain the $\mathrm{CRF}_{1} \mathrm{R}$-dependent augmented cocaine seeking in response to stress or CRF delivered into the VTA after longaccess self-administration (Blacktop et al., 2011). Altogether, the present study demonstrates a significant functional and pharmacological role of $\sigma_{1} \mathrm{R}$ in the modulation of $\mathrm{CRF}_{1} \mathrm{R}-\mathrm{OX}_{1} \mathrm{R}$ heteromers during physiological conditions and under conditions of acute cocaine administration and withdrawal. Addressing the study of $\sigma_{1} \mathrm{R}-\mathrm{CRF}_{1} \mathrm{R}-\mathrm{OX} \mathrm{X}_{1} \mathrm{R}$ oligomers in animal models of psychostimulant abuse should provide significant additional information that would support their role as new therapeutic targets.

\section{References}

Akunne HC, Whetzel SZ, Wiley JN, Corbin AE, Ninteman FW, Tecle H, Pei Y, Pugsley TA, Heffner TG (1997) The pharmacology of the novel and selective sigma ligand, PD 144418. Neuropharmacology 36:51-62. CrossRef Medline

Azdad K, Gall D, Woods AS, Ledent C, Ferré S, Schiffmann SN (2009) Dopamine D2 and adenosine $\mathrm{A} 2 \mathrm{~A}$ receptors regulate NMDA-mediated excitation in accum- 
bens neurons through A2A-D2 receptor heteromerization. Neuropsychopharmacology 34:972-986. CrossRef Medline

Blacktop JM, Seubert C, Baker DA, Ferda N, Lee G, Graf EN, Mantsch JR (2011) Augmented cocaine seeking in response to stress or CRF delivered into the ventral tegmental area following long-access self-administration is mediated by CRF receptor type 1 but not CRF receptor type 2. J Neurosci 31:11396-11403. CrossRef Medline

Borgland SL, Ungless MA, Bonci A (2010) Convergent actions of orexin/ hypocretin and CRF on dopamine neurons: emerging players in addiction. Brain Res 1314:139-144. CrossRef Medline

Boutrel B, Kenny PJ, Specio SE, Martin-Fardon R, Markou A, Koob GF, de Lecea L (2005) Role for hypocretin in mediating stress-induced reinstatement of cocaine-seeking behavior. Proc Natl Acad Sci U S A 102: 19168-19173. CrossRef Medline

Carriba P, Navarro G, Ciruela F, Ferré S, Casadó V, Agnati L, Cortés A, Mallol J, Fuxe K, Canela EI, Lluís C, Franco R (2008) Detection of heteromerization of more than two proteins by sequential BRET-FRET. Nat Methods 5:727-233. CrossRef Medline

de Lecea L, Kilduff TS, Peyron C, Gao X, Foye PE, Danielson PE, Fukuhara C, Battenberg EL, Gautvik VT, Bartlett FS 2nd, Frankel WN, van den Pol AN, Bloom FE, Gautvik KM, Sutcliffe JG (1998) The hypocretins: hypothalamus-specific peptides with neuroexcitatory activity. Proc Natl Acad Sci U S A 95:322-327. CrossRef Medline

Devigny C, Perez-Balderas F, Hoogeland B, Cuboni S, Wachtel R, Mauch CP, Webb KJ, Deussing JM, Hausch F (2011) Biomimetic screening of class-B G protein-coupled. J Am Chem Soc 133:8927-8933. CrossRef Medline

Ellis J, Pediani JD, Canals M, Milasta S, Milligan G (2006) Orexin-1 receptor-cannabinoid CB1 receptor heterodimerization results in both ligand-dependent and -independent coordinated alterations of receptor localization and function. J Biol Chem 281:38812-38824. CrossRef Medline

Ferré S, Baler R, Bouvier M, Caron MG, Devi LA, Durroux T, Fuxe K, George SR, Javitch JA, Lohse MJ, Mackie K, Milligan G, Pfleger KD, Pin JP, Volkow ND, Waldhoer M, Woods AS, Franco R (2009) Building a new conceptual framework for receptor heteromers. Nat Chem Biol 5:131134. CrossRef Medline

Ferré S, Casadó V, Devi LA, Filizola M, Jockers R, Lohse MJ, Milligan G, Pin JP, Guitart X (2014) Protein-coupled receptor oligomerization revisited: functional and pharmacological perspectives. Pharmacol Rev 66:413-434. CrossRef Medline

Garcés-Ramírez L, Green JL, Hiranita T, Kopajtic TA, Mereu M, Thomas AM, Mesangeau C, Narayanan S, McCurdy CR, Katz JL, Tanda G (2011) Sigma receptor agonists: receptor binding and effects on mesolimbic dopamine neurotransmission assessed by microdialysis. Biol Psychiatry 69: 208-217. CrossRef Medline

Guitart X, Navarro G, Moreno E, Yano H, Cai NS, Sánchez-Soto M, KumarBarodia S, Naidu YT, Mallol J, Cortés A, Lluís C, Canela EI, Casadó V, McCormick PJ, Ferré S (2014) Functional selectivity of allosteric interactions within GPCR oligomers: the dopamine D1-D3 receptor heterotetramer. Mol Pharmacol 86:417-429. CrossRef Medline

He SQ, Zhang ZN, Guan JS, Liu HR, Zhao B, Wang HB, Li Q, Yang H, Luo J, Li ZY, Wang Q, Lu YJ, Bao L, Zhang X (2011) Facilitation of $\mu$-opioid receptor activity by preventing $\delta$-opioid receptor-mediated codegradation. Neuron 69:120-131. CrossRef Medline

Jäntti MH, Mandrika I, Kukkonen JP (2014) Human orexin/hypocretin receptors form constitutive homo- and heteromeric complexes with each other and with human CB1 cannabinoid receptors. Biochem Biophys Res Commun 445:486-490. CrossRef Medline

Kita JM, Kile BM, Parker LE, Wightman RM (2009) In vivo measurement of somatodendritic release of dopamine in the ventral tegmental area. Synapse 63:951-960. CrossRef Medline

Kourrich S, Hayashi T, Chuang JY, Tsai SY, Su TP, Bonci A (2013) Dynamic interaction between sigma-1 receptor and Kv1.2 shapes neuronal and behavioral responses to cocaine. Cell 152:236-247. CrossRef Medline

Kovacs JJ, Hara MR, Davenport CL, Kim J, Lefkowitz RJ (2009) Arrestin development: emerging roles for beta-arrestins in developmental signaling pathways. Dev Cell 17:443-458. CrossRef Medline

Legault M, Wise RA (1999) Injections of N-methyl-D-aspartate into the ventral hippocampus increase extracellular dopamine in the ventral tegmental area and nucleus accumbens. Synapse 31:241-249. CrossRef Medline
Lodge DJ, Grace AA (2005) Acute and chronic corticotropin-releasing factor 1 receptor blockade inhibits cocaine-induced dopamine release: correlation with dopamine neuron activity. J Pharmacol Exp Ther 314:201-206. CrossRef Medline

Lu L, Liu Z, Huang M, Zhang Z (2003) Dopamine-dependent responses to cocaine depend on corticotropin-releasing factor receptor subtypes. J Neurochem 84:1378-1386. CrossRef Medline

Mahler SV, Moorman DE, Smith RJ, James MH, Aston-Jones G (2014) Motivational activation: a unifying hypothesis of orexin/hypocretin function. Nat Neurosci 17:1298-1303. CrossRef Medline

Maurice T, Su TP (2009) The pharmacology of sigma-1 receptors. Pharmacol Ther 124:195-206. CrossRef Medline

Mikhailova MV, Mayeux PR, Jurkevich A, Kuenzel WJ, Madison F, Periasamy A, Chen Y, Cornett LE (2007) Heterooligomerization between vasotocin and corticotropin-releasing hormone $(\mathrm{CRH})$ receptors augments CRH-stimulated $3^{\prime}, 5^{\prime}$-cyclic adenosine monophosphate production. Mol Endocrinol 21:2178-2188. CrossRef Medline

Milan-Lobo L, Gsandtner I, Gaubitzer E, Rünzler D, Buchmayer F, Köhler G, Bonci A, Freissmuth M, Sitte HH (2009) Subtype-specific differences in corticotropin-releasing factor receptor complexes detected by fluorescence spectroscopy. Mol Pharmacol 76:1196-1210. CrossRef Medline

Moreno E, Moreno-Delgado D, Navarro G, Hoffmann HM, Fuentes S, Rosell-Vilar S, Gasperini P, Rodríguez-Ruiz M, Medrano M, Mallol J, Cortés A, Casadó V, Lluís C, Ferré S, Ortiz J, Canela E, McCormick PJ (2014) Cocaine disrupts histamine $\mathrm{H} 3$ receptor modulation of dopamine D1 receptor signaling: $\sigma 1-\mathrm{D} 1-\mathrm{H} 3$ receptor complexes as key targets for reducing cocaine's effects. J Neurosci 34:3545-3558. CrossRef Medline

Murat B, Devost D, Andrés M, Mion J, Boulay V, Corbani M, Zingg HH, Guillon G (2012) V1b and CRHR1 receptor heterodimerization mediates synergistic biological actions of vasopressin and CRH. Mol Endocrinol 26:502-520. CrossRef Medline

Navarro G, Moreno E, Aymerich M, Marcellino D, McCormick PJ, Mallol J, Cortés A, Casadó V, Canela EI, Ortiz J, Fuxe K, Lluís C, Ferré S, Franco R (2010) Direct involvement of sigma-1 receptors in the dopamine D1 receptor-mediated effects of cocaine. Proc Natl Acad Sci U S A 107: 18676-18681. CrossRef Medline

Navarro G, Moreno E, Bonaventura J, Brugarolas M, Farré D, Aguinaga D, Mallol J, Cortés A, Casadó V, Lluís C, Ferre S, Franco R, Canela E, McCormick PJ (2013) Cocaine inhibits dopamine D2 receptor signaling via sigma-1-D2 receptor heteromers. PLoS One 8:e61245. CrossRef Medline

Pettit HO, Pan HT, Parsons LH, Justice JB Jr (1990) Extracellular concentrations of cocaine and dopamine are enhanced during chronic cocaine administration. J Neurochem 55:798-804. CrossRef Medline

Richards JK, Simms JA, Steensland P, Taha SA, Borgland SL, Bonci A, Bartlett SE (2008) Inhibition of orexin-1/hypocretin-1 receptors inhibits yohimbine-induced reinstatement of ethanol and sucrose seeking in Long-Evans rats. Psychopharmacology 199:109-117. CrossRef Medline

Robson MJ, Noorbakhsh B, Seminerio MJ, Matsumoto RR (2012) Sigma-1 receptors: potential targets for the treatment of substance abuse. Curr Pharm Des 18:902-919. CrossRef Medline

Rodaros D, Caruana DA, Amir S, Stewart J (2007) Corticotropin-releasing factor projections from limbic forebrain and paraventricular nucleus of the hypothalamus to the region of the ventral tegmental area. Neuroscience 150:8-13. CrossRef Medline

Saal D, Dong Y, Bonci A, Malenka RC (2003) Drugs of abuse and stress trigger a common synaptic adaptation in dopamine neurons. Neuron 37:577-582. CrossRef Medline

Sakurai T (2014) The role of orexin in motivated behaviours. Nat Rev Neurosci 15:719-731. CrossRef Medline

Sakurai T, Amemiya A, Ishii M, Matsuzaki I, Chemelli RM, Tanaka H, Williams SC, Richardson JA, Kozlowski GP, Wilson S, Arch JR, Buckingham RE, Haynes AC, Carr SA, Annan RS, McNulty DE, Liu WS, Terrett JA, Elshourbagy NA, Bergsma DJ, Yanagisawa M (1998) Orexins and orexin receptors: a family of hypothalamic neuropeptides and G proteincoupled receptors that regulate feeding behavior. Cell 92:573-585. CrossRef Medline

Sarnyai Z, Shaham Y, Heinrichs SC (2001) The role of corticotropinreleasing factor in drug addiction. Pharmacol Rev 53:209-243. Medline 
Schwarze SR, Ho A, Vocero-Akbani A, Dowdy SF (1999) In vivo protein transduction: delivery of a biologically active protein into the mouse. Science 285:1569-1572. CrossRef Medline

Shaham Y, Erb S, Leung S, Buczek Y, Stewart J (1998) CP-154,526, a selective, non-peptide antagonist of the corticotropin-releasing factor1 receptor attenuates stress-induced relapse to drug seeking in cocaine- and heroin-trained rats. Psychopharmacology 137:184-190. CrossRef Medline

Ungless MA, Singh V, Crowder TL, Yaka R, Ron D, Bonci A (2003) Corticotropin-releasing factor requires $\mathrm{CRF}$ binding protein to potentiate NMDA receptors via CRF receptor 2 in dopamine neurons. Neuron 39: 401-407. CrossRef Medline
Wang B, Shaham Y, Zitzman D, Azari S, Wise RA, You ZB (2005) Cocaine experience establishes control of midbrain glutamate and dopamine by corticotropin-releasing factor: a role in stress-induced relapse to drug seeking. J Neurosci 25:5389-5396. CrossRef Medline

Wang B, You ZB, Rice KC, Wise RA (2007) Stress-induced relapse to cocaine seeking: roles for the $\mathrm{CRF}(2)$ receptor and CRF-binding protein in the ventral tegmental area of the rat. Psychopharmacology 193:283-294. CrossRef Medline

Wang B, You ZB, Wise RA (2009) Reinstatement of cocaine seeking by hypocretin (orexin) in the ventral tegmental area: independence from the local corticotropin-releasing factor network. Biol Psychiatry 65:857-862. CrossRef Medline 